\title{
Precipitation of Calcium Phosphates and Calcium Carbonates in the Presence of Differently Charged Liposomes
}

\author{
Ina Erceg ${ }^{1}$, Jasminka Kontrec ${ }^{2}{ }^{\circledR}$, Vida Strasser ${ }^{1}\left(\right.$, Atiđa Selmani ${ }^{1}$, Darija Domazet Jurašin ${ }^{1}{ }^{\circledR}$, Marija Ćurlin ${ }^{3}$, \\ Branka Njegić Džakula ${ }^{2}{ }^{\oplus}$, Nives Matijaković Mlinarić ${ }^{2}{ }^{\infty}$, Suzana Šegota ${ }^{1}{ }^{1}$, Daniel M. Lyons ${ }^{4}$, \\ Damir Kralj ${ }^{2, *(1)}$ and Maja Dutour Sikirić ${ }^{1, *(\mathbb{D}}$
}

check for

updates

Citation: Erceg, I.; Kontrec, J.;

Strasser, V.; Selmani, A.; Domazet Jurašin, D.; Ćurlin, M.; Džakula, B.N.; Matijaković Mlinarić, N.; Šegota, S.; Lyons, D.M.; et al. Precipitation of Calcium Phosphates and Calcium Carbonates in the Presence of Differently Charged Liposomes. Minerals 2022, 12, 208. https:// doi.org/10.3390/min12020208

Academic Editor: Denis Gebauer

Received: 7 December 2021

Accepted: 4 February 2022

Published: 6 February 2022

Publisher's Note: MDPI stays neutral with regard to jurisdictional claims in published maps and institutional affiliations.

Copyright: (C) 2022 by the authors. Licensee MDPI, Basel, Switzerland. This article is an open access article distributed under the terms and conditions of the Creative Commons Attribution (CC BY) license (https:// creativecommons.org/licenses/by/ $4.0 /$ )
1 Laboratory for Biocolloids and Surface Chemistry, Division of Physical Chemistry, Ruđer Bošković Institute, Bijenička cesta 54, 10000 Zagreb, Croatia; ierceg@irb.hr (I.E.); Vida.Strasser@irb.hr (V.S.); Atidja.Selmani@irb.hr (A.S.); djurasin@irb.hr (D.D.J.); ssegota@irb.hr (S.Š.)

2 Laboratory for Precipitation Processes, Division of Materials Chemistry, Ruđer Bošković Institute, Bijenička cesta 54, 10000 Zagreb, Croatia; lugaric@irb.hr (J.K.); branka.njegic.dzakula@irb.hr (B.N.D.); nives.matijakovic@irb.hr (N.M.M.)

3 School of Medicine, Catholic University of Croatia, 10000 Zagreb, Croatia; marija.curlin@unicath.hr

4 Center for Marine Research, Ruđer Bošković Institute, Giordano Pagliaga 5, 52210 Rovinj, Croatia; lyons@cim.irb.hr

* Correspondence: kralj@irb.hr (D.K.); sikiric@irb.hr (M.D.S.)

\begin{abstract}
Liposomes (lipid vesicles) are often considered to be a versatile tool for the synthesis of advanced materials, as they allow various control mechanisms to tune the materials' properties. Among diverse materials, the synthesis of calcium phosphates $(\mathrm{CaPs})$ and calcium carbonates $\left(\mathrm{CaCO}_{3}\right)$ using liposomes has attracted particular attention in the development of novel (bio)materials and biomineralization research. However, the preparation of materials using liposomes has not yet been fully exploited. Most of the liposomes used have been anionic and/or zwitterionic, while data on the influence of cationic liposomes are limited. Therefore, the aim of this study was to investigate and compare the influence of differently charged liposomes on $\mathrm{CaPs}$ and $\mathrm{CaCO}_{3}$ formation. Zwitterionic 1,2-dimyristoyl-sn-glycero-3-phosphocholine (DMPC), negatively charged 1,2-dimyristoyl-sn-glycero3-phospho-L-serine (DMPS), and positively charged 1,2-dioleoyl-sn-glycero-3-ethylphosphocholine (EPC) lipids were used to prepare the respective liposomes. The presence of liposomes during the spontaneous precipitation of $\mathrm{CaPs}$ and $\mathrm{CaCO}_{3}$ affected both the precipitation and transformation kinetics, as well as the morphology of the precipitates formed. The most prominent effect was noted for both materials in the presence of DMPS liposomes, as (nano) shell structures were formed in both cases. The obtained results indicate possible strategies to fine-tune the precipitation process of CaPs and $\mathrm{CaCO}_{3}$, which may be of interest for the production of novel materials.
\end{abstract}

Keywords: calcium phosphates; calcium carbonates; liposomes; amorphous phases; nanoshells

\section{Introduction}

The ever-increasing need for novel and advanced materials is creating a stimulus for the development of new economically acceptable and environmentally friendly synthetic routes. Accordingly, biomimetic processes inspired by the formation of hard tissues in organisms are receiving special attention [1]. Biological hard tissues are essentially organic-inorganic composites in which the organic matrix strictly controls the composition, structure, morphology, and orientation of biominerals [2]. In addition to the protein matrix, the self-assembled structures of lipids (i.e., vesicles) also play an important role in the formation of hard tissues in both vertebrates and invertebrates [3-7]. Mineralization in or at a compartmentalized reaction environment, such as that in lipid vesicles, allows the precise control of physicochemical conditions, which in turn allows the control of the mineralization process [3]. Typical examples of such a biomineralization strategy are 
coccoliths formed in the alga Emiliania huxleyi [8], matrix vesicles in vertebrates [4,9], or magnetosomes [10].

For this reason, self-assembled lipid vesicles, so-called liposomes, are attracting much attention both as model systems for a thorough understanding of biomineralization processes and as a versatile route in the synthesis of materials [11-14]. The ability of lipids to self-assemble is a consequence of their amphiphilic nature. Lipid molecules contain a polar head group, one or more hydrophobic tails, and a backbone group that binds them together $[3,11]$. Each structural element of the lipid molecule can occur in a variety of different moieties, so the size, surface charge, permeability, fluidity, and charge density of the liposome [15] can be tailored to the intended application. Moreover, they can be used in various biomedical applications due to their biocompatibility and low toxicity $[3,11,14,16,17]$.

Two classes of biominerals, calcium phosphates $(\mathrm{CaPs})$ and calcium carbonates $\left(\mathrm{CaCO}_{3}\right)$, are of particular interest, both as major mineral constituents of biological hard tissues $[2,18,19]$ and because of their various technological and biomedical applications [20-22].

$\mathrm{CaPs}$ are sparingly soluble salts of phosphoric acid that occur in the form of various compounds [19]. The main phases relevant to biomineralization are amorphous calcium phosphate (ACP), octacalcium phosphate (OCP, $\left.\mathrm{Ca}_{8}\left(\mathrm{HPO}_{4}\right)_{2}\left(\mathrm{PO}_{4}\right)_{4} \cdot 5 \mathrm{H}_{2} \mathrm{O}\right)$, calcium hydrogen phosphate dihydrate (DCPD, $\left.\mathrm{CaHPO}_{4} \cdot 2 \mathrm{H}_{2} \mathrm{O}\right)$, calcium-deficient apatite (CaDHA, $\left.\mathrm{Ca}_{10-x}\left(\mathrm{HPO}_{4}\right)_{x}\left(\mathrm{PO}_{4}\right)_{6-x}(\mathrm{OH})_{2-x}, 0<x<1\right)$, and hydroxyapatite (HAP, $\left.\mathrm{Ca}_{10}\left(\mathrm{PO}_{4}\right)_{6}(\mathrm{OH})_{2}\right)[19,23]$. They are found in various organisms, such as bacteria and vertebrates [24]. In addition to their role as a major constituent of normal and pathological hard tissues of vertebrates, CaPs are important in primitive organisms for the storage and regulation of essential elements $[19,25]$.

Calcium carbonates occur in the form of various polymorphs (calcite, aragonite, and vaterite) and hydrates (monohydrate, hexahydrate, and amorphous (ACC)). Of these, calcite and aragonite are regularly deposited as biominerals. They are the most abundant biominerals in invertebrates such as mollusks, sponges, corals, and crustaceans [26]. The ability of both $\mathrm{CaP}$ and $\mathrm{CaCO}_{3}$ to crystallize via an amorphous precursor phase is important for their function as biominerals because different ions and macromolecules can regulate this process and thus the properties of the final material [2,5,27-29].

In vitro studies have shown that liposomes provide two main sites for the formation of $\mathrm{CaP}$ and $\mathrm{CaCO}_{3}$ : the inner and the outer surface [30-36]. The permeability of liposomes to constituent ions can be influenced by liposome composition, temperature, and the inclusion of ionophores [11,37]. The negatively charged head groups of phospholipids attract calcium ions, leading to the formation of a locally supersaturated zone that can increase the nucleation rate [38]. When precipitation is initiated inside liposomes, different $\mathrm{CaP}$ phases can form depending on the experimental conditions (e.g., reactant concentration and $\mathrm{pH})[37,39-42]$. Although ACP is somewhat stabilized in the presence of liposomes compared to systems without liposomes, it continues to transform into an apatitic phase [37,42]. In contrast, the transformation of ACC within liposomes is inhibited by liposomal encapsulation and the exclusion of impurities that can act as nucleators [43,44]. However, this is not the only observed difference in the behavior of $\mathrm{CaP}$ and $\mathrm{CaCO}_{3}$ in the presence of liposomes. While the incorporation of phosphatidic acid (PA) or phosphatidylserine (PS) into the lipid membrane promotes CaP formation [35], acidic phospholipids that can bind calcium (PA, PS, or phosphatidylinositol (PI)) do not increase the interaction between the membrane and calcium or affect the nucleation and growth of $\mathrm{CaCO}_{3}[11,43]$.

In addition to the lipid composition, the properties of the outer surfaces of liposomes can be tailored by changing their size and, consequently, their curvature. This may influence the physical/chemical properties of the precipitate formed under respective conditions [31]. Indeed, many researchers have reported the preparation of porous [45] or void micro- and nanoshells [14,31], which can then be used as drug carriers [46] using liposomes as templates. Zwitterionic or anionic phospholipids such as phosphatidylcholine [30,47], dipalmitoylphosphatidylcholine (DPPC) [33], dioleayl-sn-glycero-3-phosphate and dipalmitoylsn-glycero-3-phosphate (DOPA and DPPA) [31,32], enzymatically modified DPPC [35], 
polysaccharide-coated dimyristoylphosphatidylcholine (DMPC) and dilauroyl phosphatidic acid (DLPA) [48], lecithin [36], and 3D chitosan [34] have been used to study the role of the organic template in modulating calcium phosphate or calcium carbonate formation. However, it was shown that positively charged liposomes exhibited significantly higher adsorption on HAP [49]. The selection of specific lipid molecules enables the tuning of the liposome melting temperature, i.e., liposome permeability, and thus the control of the precipitation initiated at the particular temperature of interest [40]. The mineralization of liposomes can typically be achieved by the titration method [31,32] or by the suspension of liposomes in simulated body fluid (SBF) [30,47]. No mineralization was observed when liposomes were suspended in a metastable external solution [50], so coating the liposomes with polysaccharides was proposed as a way to facilitate this process [48]. Research in which the gas diffusion method was applied showed the influence of the spatial arrangement of lecithin molecules, controlled by the lecithin concentration in calcium chloride solution, on the templating texture, polymorphism, size, and shape of calcium carbonate crystals [51].

Investigations of the influence of liposomes on the spontaneous precipitation of either $\mathrm{CaP}$ or $\mathrm{CaCO}_{3}$ are scarce. In addition, to the best of our knowledge, there has been no attempt to compare the influence of liposomes containing different head groups, i.e., different charges, on the precipitation of different $\mathrm{CaP}$ and $\mathrm{CaCO}_{3}$ phases.

To fill this gap in data, we investigated the influence of liposomes prepared from three differently charged lipids on $\mathrm{CaP}$ and $\mathrm{CaCO}_{3}$ precipitation. In particular, zwitterionic 1,2-dimyristoyl-sn-glycero-3-phosphocholine (DMPC), negatively charged 1,2-dimyristoylsn-glycero-3-phospho-L-serine (DMPS), and positively charged 1,2-dioleoyl-sn-glycero3-ethylphosphocholine (EPC) (Figure S1) were used, and the effects could be compared because the melting points of all lipids are below $37^{\circ} \mathrm{C}$. In this way, it was possible to determine both the influence of different sizes and charges of liposomes on the $\mathrm{CaP}$ and $\mathrm{CaCO}_{3}$ precipitation/transformation process and the properties of the thus-formed solids. This work is a continuation of our previous research, in which the properties of metastable and stable $\mathrm{CaP}$ and $\mathrm{CaCO}_{3}$ phases, formed under similar experimental conditions, were compared [52,53]. The obtained results could contribute to the understanding of the additional details of general principles of biomineralization and to the development of new green synthesis routes.

\section{Materials and Methods}

\subsection{Materials}

The phospholipids 1,2-dimyristoyl-sn-glycero-3-phosphocholine (DMPC), 1,2-dimyristoylsn-glycero-3-phospho-L-serine (DMPS), and 1,2-dioleoyl-sn-glycero-3-ethylphosphocholine (EPC) were purchased from Avanti Polar Lipids (Birmingham, AL). Calcium chloride dihydrate $\left(\mathrm{CaCl}_{2} \cdot 2 \mathrm{H}_{2} \mathrm{O}\right)$, disodium hydrogen phosphate $\left(\mathrm{Na}_{2} \mathrm{HPO}_{4}\right)$, sodium hydrogen carbonate $\left(\mathrm{NaHCO}_{3}\right)$, sodium carbonate $\left(\mathrm{Na}_{2} \mathrm{CO}_{3}\right)$, and sodium chloride $(\mathrm{NaCl})$ were obtained from Sigma Aldrich. $\mathrm{CaCl}_{2}, \mathrm{Na}_{2} \mathrm{HPO}_{4}, \mathrm{NaHCO}_{3}$, and $\mathrm{Na}_{2} \mathrm{CO}_{3}$ stock solutions were prepared from analytical grade chemicals that were dried overnight in a desiccator over silica gel. The exact concentrations of $\mathrm{CaCl}_{2}$ stock solution were determined by ion chromatography. The $\mathrm{pH}$ of the solutions was adjusted with hydrochloric acid $(\mathrm{HCl})$ or sodium hydroxide $(\mathrm{NaOH})$ if necessary. Milli- $\mathrm{Q}$ water was used in all experiments.

\subsection{Liposome Preparation}

Liposomes were prepared by hydration of a thin phospholipid film. In short, the lipid films were prepared as follows: $3 \mathrm{mg}$ of lipid (Figure S1) was added to $2 \mathrm{~mL}$ of chloroform, and the thin lipid film was obtained by evaporation of the solvent using a rotary evaporator. Suspensions of the liposomes were prepared by hydrating the films with Milli-Q water. The milky-white multilamellar liposome dispersions were prepared by repetition of heating and freezing cycles, followed by gentle vortexing. 


\subsection{Precipitation Systems}

The experiments were performed in a thermostated, double-walled glass vessel with a $50 \mathrm{~cm}^{3}$ capacity at $25^{\circ} \mathrm{C}$. In the $\mathrm{CaCO}_{3}$ precipitation experiments, the vessel was tightly closed with a Teflon cover, thus minimizing the exchange of carbon dioxide between the ambient air and the reaction system.

In the control precipitation systems, equal volumes $\left(20 \mathrm{~cm}^{3}\right)$ of equimolar $\mathrm{CaCl}_{2}$ and $\mathrm{Na}_{2} \mathrm{HPO}_{4}$ or $\mathrm{NaHCO}_{3} / \mathrm{Na}_{2} \mathrm{CO}_{3}$ reactant solutions were used. In the case of CaP systems, anionic and cationic solutions were simultaneously added to the reaction vessel, while in the case of $\mathrm{CaCO}_{3}$, the $\mathrm{CaCl}_{2}$ solution was rapidly added to the $\mathrm{NaHCO} / \mathrm{Na}_{2} \mathrm{CO}_{3}$ solution. The total initial concentrations of reactants (calcium, phosphate, and carbonate) in the precipitation system were: $c_{\mathrm{i}}(\mathrm{Ca})=c_{\mathrm{i}}\left(\mathrm{PO}_{4}\right)=3.5 \mathrm{mmol} \mathrm{dm}{ }^{-3}$ at $\mathrm{pH}_{\mathrm{i}}=7.40$ for CaP systems and $c_{\mathrm{i}}(\mathrm{Ca})=c_{\mathrm{i}}\left(\mathrm{CO}_{3}\right)=20 \mathrm{mmol} \mathrm{dm}{ }^{-3}\left(c_{\mathrm{i}}\left(\mathrm{HCO}_{3}\right)=19.2 \mathrm{mmol} \mathrm{dm}{ }^{-3}\right.$ and

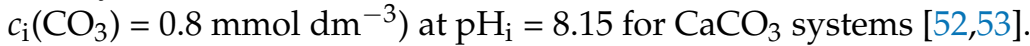

Precipitation systems containing liposomes $(2.5 \mathrm{ppm}<\gamma$ (lipid) $<25.0 \mathrm{ppm})$ were prepared by adding the respective liposome suspensions to the anionic reactant solution before mixing the reactant solutions and readjusting the $\mathrm{pH}$ if necessary.

The progress of the reaction was followed by measuring the $\mathrm{pH}$ of the solution using a combined glass-calomel electrode connected to a digital $\mathrm{pH}$ meter (Metrohm 701 or Radiometer PHM 290 pH/ion meter).

\subsection{Characterization}

\subsubsection{Characterization of Liposomes}

Infrared spectra (Figures S2-S4, Tables S1-S3) of the lipids were obtained by using attenuated total reflection FTIR (ATR-FTIR Tensor II spectrometer, Bruker, Ettlingen, Germany).

The size distribution and zeta potential of the liposomes were determined by dynamic (DLS) and electrophoretic light scattering (ELS) using a Zetasizer Nano ZS (Malvern Instruments, Malvern, UK) equipped with a $532 \mathrm{~nm}$ "green" laser. The intensity of scattered light was detected at a backscattering angle of $173^{\circ}$ to reduce multiple scattering, as well as the effects of dust. To avoid overestimation arising from the scattering of larger particles, the hydrodynamic diameter $\left(d_{\mathrm{h}}\right)$ was obtained as the value at the peak maximum of the volume size distribution. Each sample was measured 10 times. The zeta potentials $(\zeta)$ of the particles were calculated from the measured electrophoretic mobility with the Henry equation using the Smoluchowski approximation $(f(\kappa a)=1.5)$. Results are reported as an average value of 3 measurements. For the data processing, Zetasizer software v6.32 (Malvern Instruments) was used. Both DLS and ELS measurements were performed at $\vartheta=25^{\circ} \mathrm{C}$. The measured hydrodynamic diameter and zeta potential of the prepared liposomes are presented in Table S4.

\subsubsection{Characterization of Precipitates}

Precipitates were filtered through a $0.45 \mu \mathrm{m}$ Millipore filter at predetermined time intervals, washed 3 times with Milli-Q water and once with ethanol, and dried in a stream of nitrogen $(\mathrm{CaP})$ or at $100{ }^{\circ} \mathrm{C}\left(\mathrm{CaCO}_{3}\right)$. Samples were kept in a desiccator until further analysis.

Powder X-ray diffraction (PXRD) patterns were collected by Rigaku Ultima IV diffractometer (Rigaku, Tokyo, Japan) in Bragg-Brentano parafocusing geometry using CuK $\alpha$ radiation and $5^{\circ}$ Soller slits. Scans were performed in $0.02^{\circ} 2 \theta$ steps in the range from 3.25 to $60^{\circ} 2 \theta$ with a scan speed of $1^{\circ}$ per min. The baselines of PXRD patterns were corrected, and when needed, the data were smoothed using a 5-point adjacent-averaging algorithm.

Infrared spectra were recorded on an FTIR spectrometer equipped with an attenuated total reflection module (Tensor II, Bruker, Ettlingen, Germany) with diamond ATR crystal from $4000-400 \mathrm{~cm}^{-1}$, with a resolution of $2 \mathrm{~cm}^{-1}$. The spectra are the average of 32 scans.

Thermogravimetric measurements (TG) of the dried $\mathrm{CaCO}_{3}$ samples were carried out on a Mettler TG 50 thermobalance (Mettler Toledo Corp., Zürich, Switzerland) equipped with a TC $10 \mathrm{TA}$ processor (heating rate $10 \mathrm{~K} \mathrm{~min}^{-1}$ ). 
The morphology of the obtained precipitates was analyzed by scanning electron microscopy (JEOL JSM-7000F FE-SEM microscope, Jeol, Tokyo, Japan) and transmission electron microscopy (Zeiss TEM 902A, Zeiss, Oberkochen, Germany and JEOL JEM-1010, $80 \mathrm{kV}$, Jeol, Tokyo, Japan). The sizes of ACP and ACC particles were estimated from TEM micrographs using the ImageJ (v.1.46r) freeware program.

\section{Results and Discussion}

Despite the continuous interest that calcium phosphates and calcium carbonates attract due to their role in biomineralization and importance in materials science [29,54,55], the mechanisms of their formation are not yet fully elucidated. Although these two biominerals do occur in different organisms, similarities in their formation mechanisms and physiological roles exist [29]. There are several indications that during the early stages of mineralization at physiological conditions, in systems in which both anions are present, interactions between these two solid phases occur, as well as the possible incorporation of phosphate into the $\mathrm{CaCO}_{3}$ structure [56]. However, there is also some strong evidence that the phosphate stabilizes the transient amorphous $\mathrm{CaCO}_{3}$ phase $[57,58]$. From a materials science point of view, the relationship between the $\mathrm{CaP}$ and $\mathrm{CaCO}_{3}$ phases is important as well, since $\mathrm{CaP}$ can be prepared from $\mathrm{CaCO}_{3}$, which serves as a source of $\mathrm{Ca}^{2+}$ ions and a nucleation center $[59,60]$. Therefore, it was proposed that comparing their formation mechanisms under various conditions could be a suitable approach to contribute to revealing certain biomineralization mechanisms [61]. This approach has not yet been fully exploited due to the considerably different experimental conditions required for the precipitation of these two types of biominerals.

The $\mathrm{CaP}$ and $\mathrm{CaCO}_{3}$ precipitation systems investigated in this study comprised reactant concentrations and $\mathrm{pH}$ relevant to the corresponding physiological conditions. In both systems, precipitation occurred rapidly and commenced immediately upon mixing the reactant solutions. Both precipitation systems were supersaturated with respect to the relevant solid phases, including the corresponding metastable phases [53], to be able to assess the influence of liposomes on polymorphic selection and the mechanism of their formation (transformation).

\subsection{Influence of the Liposomes on Precipitation of Calcium Phosphates}

In neutral and basic solutions, CaPs usually precipitate in two steps. The first step is the formation of an amorphous precursor, $\mathrm{ACP}$, which subsequently transforms into a more stable, crystalline phase(s) [23,62-64]. Precipitation of CaP was followed by monitoring changes in the suspension $\mathrm{pH}$, as shown previously [62,65-69]. In Figure 1, the representative $\mathrm{pH}$ curves obtained in the control system (i.e., without liposomes) and systems containing different concentrations of liposomes (expressed as lipid concentration) are shown. All curves have a typical sigmoidal shape, which indicates three stages of the precipitation process. The initial slight decrease in $\mathrm{pH}$ can be associated with the formation of $\mathrm{ACP}$, while a subsequent abrupt $\mathrm{pH}$ decrease is a consequence of the formation and crystal growth of a specific phase on preformed ACP. The final slight change in $\mathrm{pH}$ is associated with solution-mediated transformation and ripening of the crystalline phase $[23,62,65-69]$. The similar shapes of the obtained $\mathrm{pH}$ curves could indicate that there is no significant difference in the mechanism of $\mathrm{CaP}$ formation in the presence of different liposomes.

However, differences could be observed in the induction times of crystalline phase formation $\left(t_{i}\right.$, Table 1$)$, which represent the time elapsed between the commencement of the precipitation reaction (mixing of the reactants) and the first appearance of the crystalline phase upon the previously formed ACP. The induction time can be determined from the intersection of the tangents on the first and second parts of the $\mathrm{pH}$ vs. time curve [23,62]. Frequently, induction time is used as an indicator of ACP stability, and it is accepted that a longer induction time corresponds to a more stable ACP [62,70]. The obtained results indicated different tendencies of the $t_{\mathrm{i}}$ changes with the liposome concentration (Figure $1 \mathrm{~b}$ ). In the presence of zwitterionic DMPC liposomes, the induction time increased, while in 
the presence of negatively charged DMPS, it decreased with the concentration of the lipid. However, the influence of EPC on induction time was negligible. The effect of DMPS could be ascribed to the high affinity of PS groups for $\mathrm{Ca}^{2+}$ ions, which adsorbed on the outer liposomal membrane and could serve as a template for the formation of $\mathrm{CaP}$, thus promoting the ACP transformation. This finding is opposite to that in a previous study by Wuthier and Eans [71], in which the authors showed that PS liposomes enhanced the stability of prepared ACP proportionally to the applied concentration (200-1000 ppm PS). The stabilization was less pronounced when PS was present during spontaneous ACP precipitation. The PS concentrations used by Wuthier and Eans [71] were much higher than those used in the spontaneous precipitation experiment described in this work, which could explain the observed differences. A recent computational study showed that $\mathrm{Ca}^{2+}-\mathrm{HPO}_{4}{ }^{2-}$ and phosphatidylserine complexes facilitate nucleation [72]. It was also shown that prepared ACP was more stable in the presence of PC, diacetyl phosphate, and cholesterol liposomes [37].
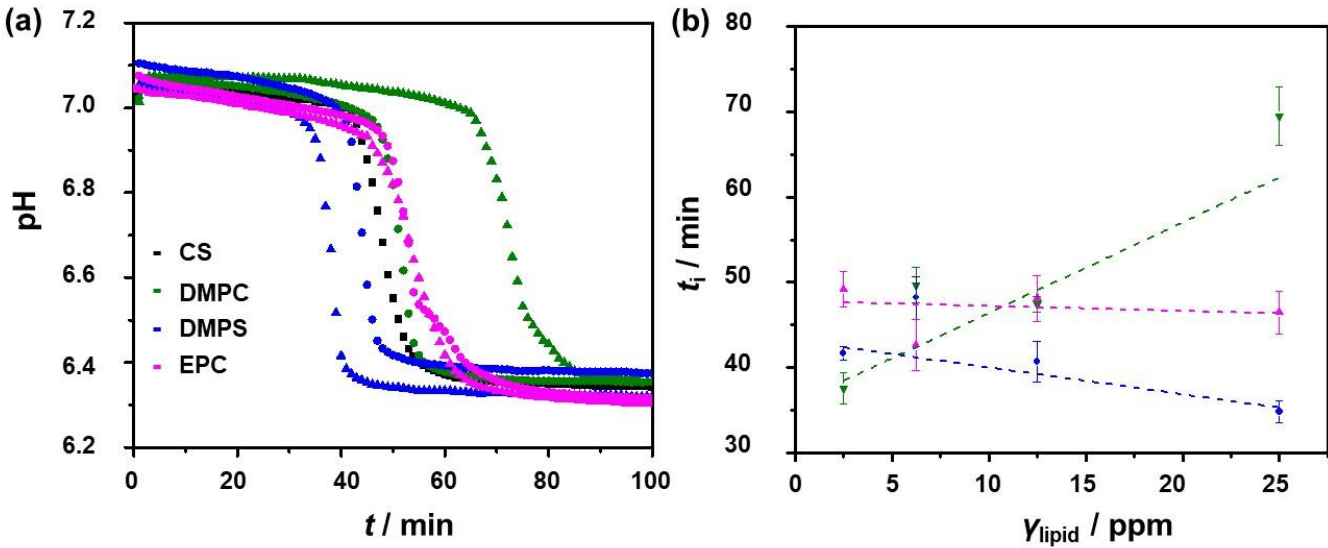

Figure 1. (a) Representative $\mathrm{pH}$ vs. time progress curve of formation and transformation of calcium phosphate solid phases in the absence (CS) and presence of $12.5 \mathrm{ppm}$ (spheres) and $25.0 \mathrm{ppm}$ (triangles) lipids. (b) The dependence of average induction time ( $t_{\mathrm{i}}$, calculated from $\mathrm{pH}$ vs. time curves) on lipid concentration is given. $c_{\mathrm{i}}(\mathrm{Ca})=c_{\mathrm{i}}\left(\mathrm{PO}_{4}\right)=3.5 \mathrm{mmol} \mathrm{dm}^{-3} ; \mathrm{pH}_{\mathrm{i}}=7.4 ; \vartheta /{ }^{\circ} \mathrm{C}=25 \pm 0.1$.

Table 1. Average induction times $\left(t_{\mathrm{i}}\right)$ obtained from $\mathrm{pH}$ vs. time $(t)$ curves from 3 measurements with standard deviations (SDs). $c_{\mathrm{i}}(\mathrm{Ca})=c_{\mathrm{i}}\left(\mathrm{PO}_{4}\right)=3.5 \mathrm{mmol} \mathrm{dm}{ }^{-3} ; \mathrm{pH}_{\mathrm{i}}=7.4 ; \vartheta /{ }^{\circ} \mathrm{C}=25 \pm 0.1$. Liposome concentrations are expressed as lipid concentration.

\begin{tabular}{ccc}
\hline Precipitation System & $\gamma$ (Lipid)/ppm & $\boldsymbol{t}_{\mathbf{i}} / \mathbf{m i n}$ \\
\hline CS & 0 & $42.6 \pm 2.3$ \\
\hline DMPC & 2.5 & $37.6 \pm 1.8$ \\
DMPC & 6.25 & $49.7 \pm 2.1$ \\
DMPC & 12.5 & $47.4 \pm 0.9$ \\
DMPC & 25.0 & $69.5 \pm 3.4$ \\
\hline DMPS & 2.5 & $41.7 \pm 0.8$ \\
DMPS & 6.25 & $48.2 \pm 2.5$ \\
DMPS & 12.5 & $40.7 \pm 2.4$ \\
DMPS & 25.0 & $34.8 \pm 1.3$ \\
\hline EPC & 2.5 & $49.2 \pm 2.1$ \\
EPC & 6.25 & $42.7 \pm 3.0$ \\
EPC & 12.5 & $48.1 \pm 2.7$ \\
EPC & 25.0 & $46.5 \pm 2.5$ \\
\hline
\end{tabular}

Precipitates were initially characterized by TEM after $30 \mathrm{~min}$ of reaction due to the small amount of formed precipitate (Figure 2). In all investigated systems, selected area electron diffraction (SAED) patterns showed the presence of an amorphous phase. In 
the control system, as well as in the presence of DMPC and DMPS liposomes, typical chain-like aggregates of spherical ACP particles were observed [52,62,65,73]. However, the sizes of small spherical particles obtained in the presence of specific liposomes were different. Particles with the smallest average diameter $(79.1 \pm 10.9 \mathrm{~nm})$ and with a narrow size distribution (Figure S5) were obtained in the control system, while those formed in the presence of DMPC liposomes were larger $(127.0 \pm 17.5 \mathrm{~nm})$ and somewhat elongated. Similarly, in the presence of DMPS, the particles were elongated, but their size distribution was wider, ranging from 60 to $180 \mathrm{~nm}$ with an average size of $110.8 \pm 21.2 \mathrm{~nm}$. However, completely different ACP morphology was noted in the EPC liposomal systems, in which a gel-like precipitate was obtained [74].
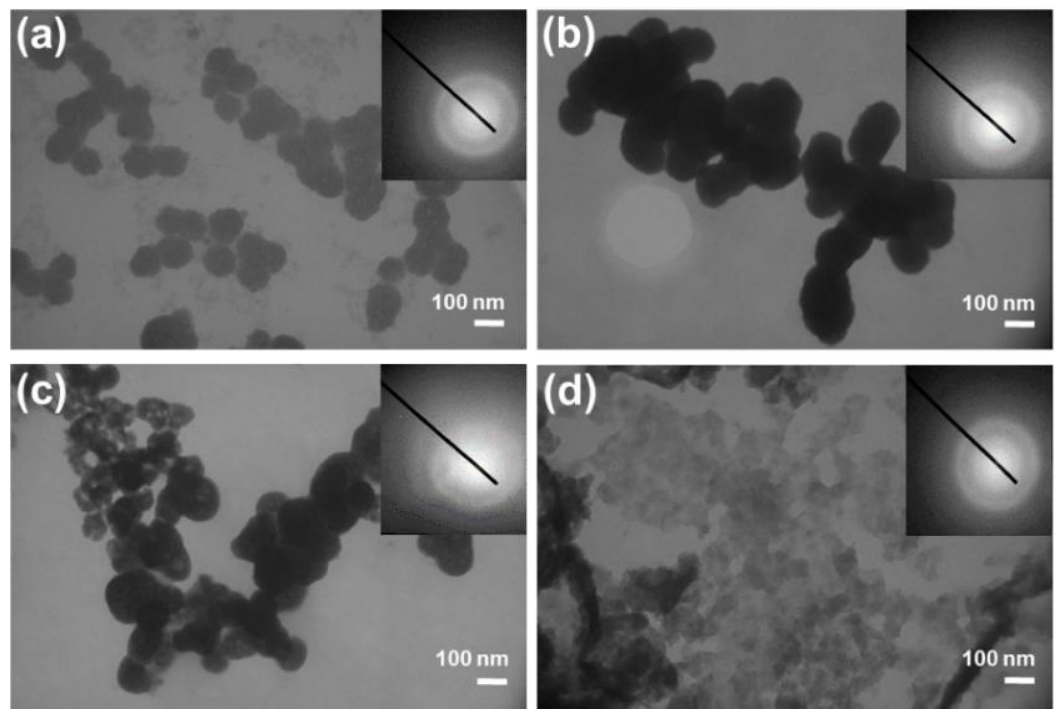

Figure 2. TEM micrographs and corresponding SAED patterns (insets in the figures) of precipitates formed in (a) control system and in the presence of (b) DMPC, (c) DMPS, and (d) EPC liposomes. $c_{\mathrm{i}}(\mathrm{Ca})=c_{\mathrm{i}}\left(\mathrm{PO}_{4}\right)=3.5 \mathrm{mmol} \mathrm{dm}{ }^{-3} ; \gamma($ lipid $)=25.0 \mathrm{ppm} ; \mathrm{pH}_{\mathrm{i}}=7.4, \vartheta /{ }^{\circ} \mathrm{C}=25 \pm 0.1$; after $30 \mathrm{~min}$ aging time.

A likely explanation for the observed differences in the morphology of ACP obtained in different liposomal systems can be related, apart from their chemical differences, to differences in the size and zeta potential (Table S4). However, in the applied anionic phosphate reactant solution, different liposomes did differ in both size and zeta potential. In particular, zwitterionic DMPC formed large liposomes with bimodal size distributions that peaked at 1610.6 and $4877.8 \mathrm{~nm}$ and with a zeta potential of $-0.6 \mathrm{mV}$. DMPS formed much smaller liposomes $(231 \mathrm{~nm})$ but with a more negative zeta potential $(-100.6 \mathrm{mV})$. The size distribution of EPC liposomes was also bimodal, but the liposomes were also smaller than DMPC liposomes. Liposomes with average sizes of 44.8 and $308.1 \mathrm{~nm}$ and with a zeta potential of $56.6 \mathrm{mV}$ were observed. As the effects of size and zeta potential could not be decoupled under the applied experimental condition, the explanation of the observed differences is rather complex.

PXRD patterns, FTIR spectra, and SEM micrographs of the CaP precipitate obtained after $60 \mathrm{~min}$ are presented in Figures 3 and 4, respectively. Similar to polyelectrolytes [62] and surfactants [65] under similar experimental conditions, liposomes did not influence the composition of the precipitates. FTIR spectra (Figure 3a,c,e, Tables S5-S8) of all samples show typical phosphate and water bands. The asymmetric stretching mode of $\mathrm{PO}_{4}^{3-}$ was found at around $1114 \mathrm{~cm}^{-1}$ and $1020 \mathrm{~cm}^{-1}$, and symmetric stretching was observed at $960 \mathrm{~cm}^{-1}$, with bending modes of $\mathrm{PO}_{4}^{3-}$ at around $600 \mathrm{~cm}^{-1}, 555 \mathrm{~cm}^{-1}$, and $470 \mathrm{~cm}^{-1}$. The band at around $860 \mathrm{~cm}^{-1}$ corresponds to $\mathrm{HPO}_{4}^{2-}$ vibration. A broad band at $3700-2600 \mathrm{~cm}^{-1}$, as well as a band at $1650 \mathrm{~cm}^{-1}$, corresponds to the vibration of water molecules [75,76]. No bands characteristic of lipids were observed. In PXRD patterns, peaks at around $25.91^{\circ}$ and 
$32.12^{\circ} 2 \theta$, characteristic of CaDHA, were observed $[77,78]$. In the case of DMPS and EPC, the intensity of these peaks decreased with the increase in concentration, although at the highest applied concentrations, the intensity was the highest. However, the intensity of the peaks continuously increased with the DMPC concentration.

(a)

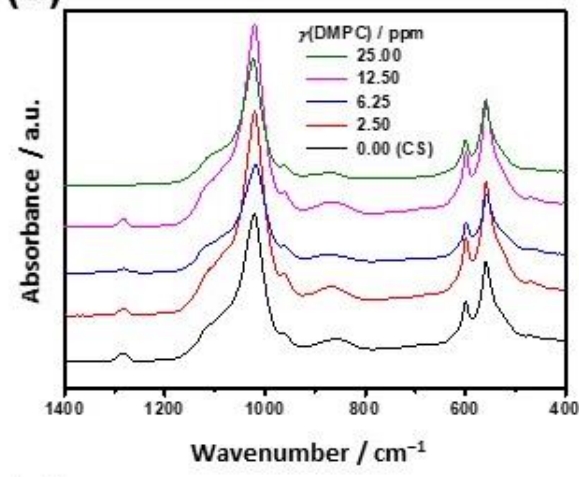

(c)

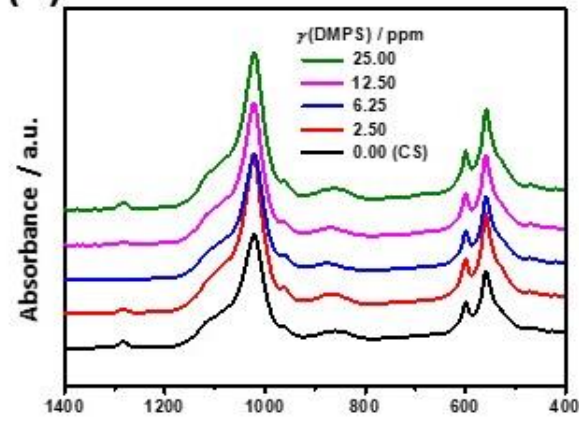

(e)

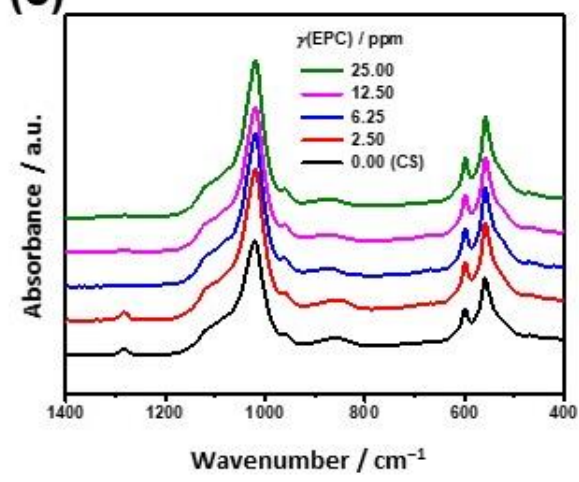

(b)

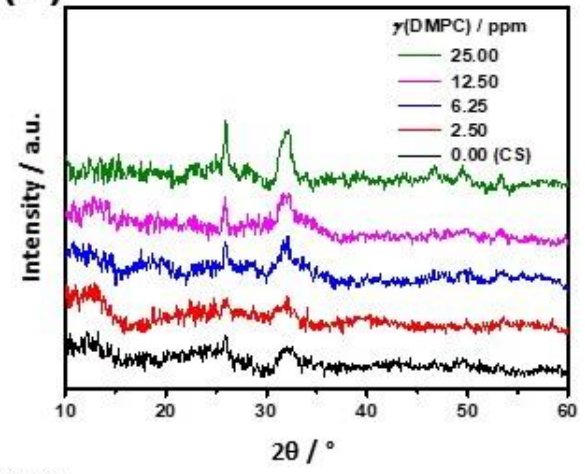

(d)

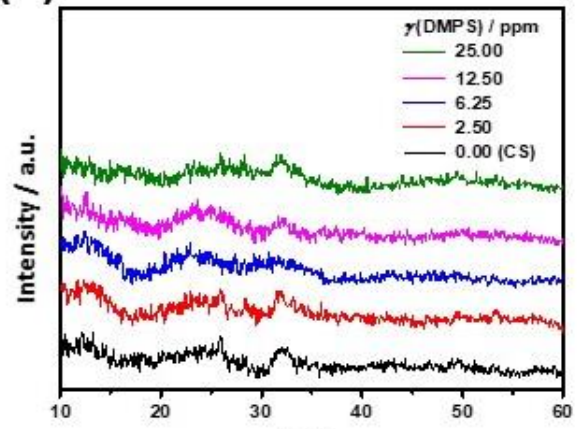

(f)

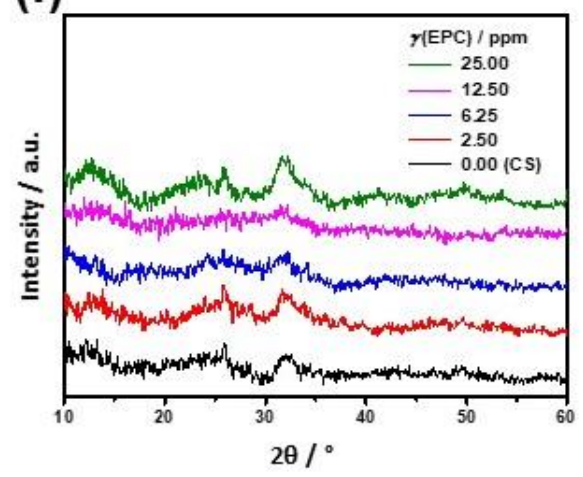

Figure 3. FTIR spectra $(\mathbf{a}, \mathbf{c}, \mathbf{e})$ and PXRD patterns $(\mathbf{b}, \mathbf{d}, \mathbf{f})$ of the CaP precipitate formed after 60 min of aging in the absence (CS) and presence of different concentrations of liposomes (expressed as lipid concentration): (a,b) DMPC, (c,d) DMPS, and (e,f) EPC. $c_{\mathrm{i}}(\mathrm{Ca})=c_{\mathrm{i}}\left(\mathrm{PO}_{4}\right)=3.5 \mathrm{mmol} \mathrm{dm}{ }^{-3} ; \mathrm{pH}_{\mathrm{i}}=7.4$; $\vartheta /{ }^{\circ} \mathrm{C}=25 \pm 0.1$.

The morphologies of the precipitates were correlated with different liposomes present during their formation (Figure 4). Typical spherical aggregates of leaf-like CaDHA crystals were obtained in the control system (Figure 4a), as well as in the presence of DMPC (Figure $4 b$ ) and EPC (Figure 4c). However, in the presence of DMPC, spherical aggregates were somewhat larger and denser than those in the control system, while the single leaflike crystals were less developed and smaller. In the presence of EPC, smaller spherical aggregates were observed. SEM micrographs of precipitate formed in the presence of DMPS (Figure $4 \mathrm{~d}, \mathrm{e}$ ) reveal that some of the spherical aggregates are hollow, which indicates nanoshell formation. 

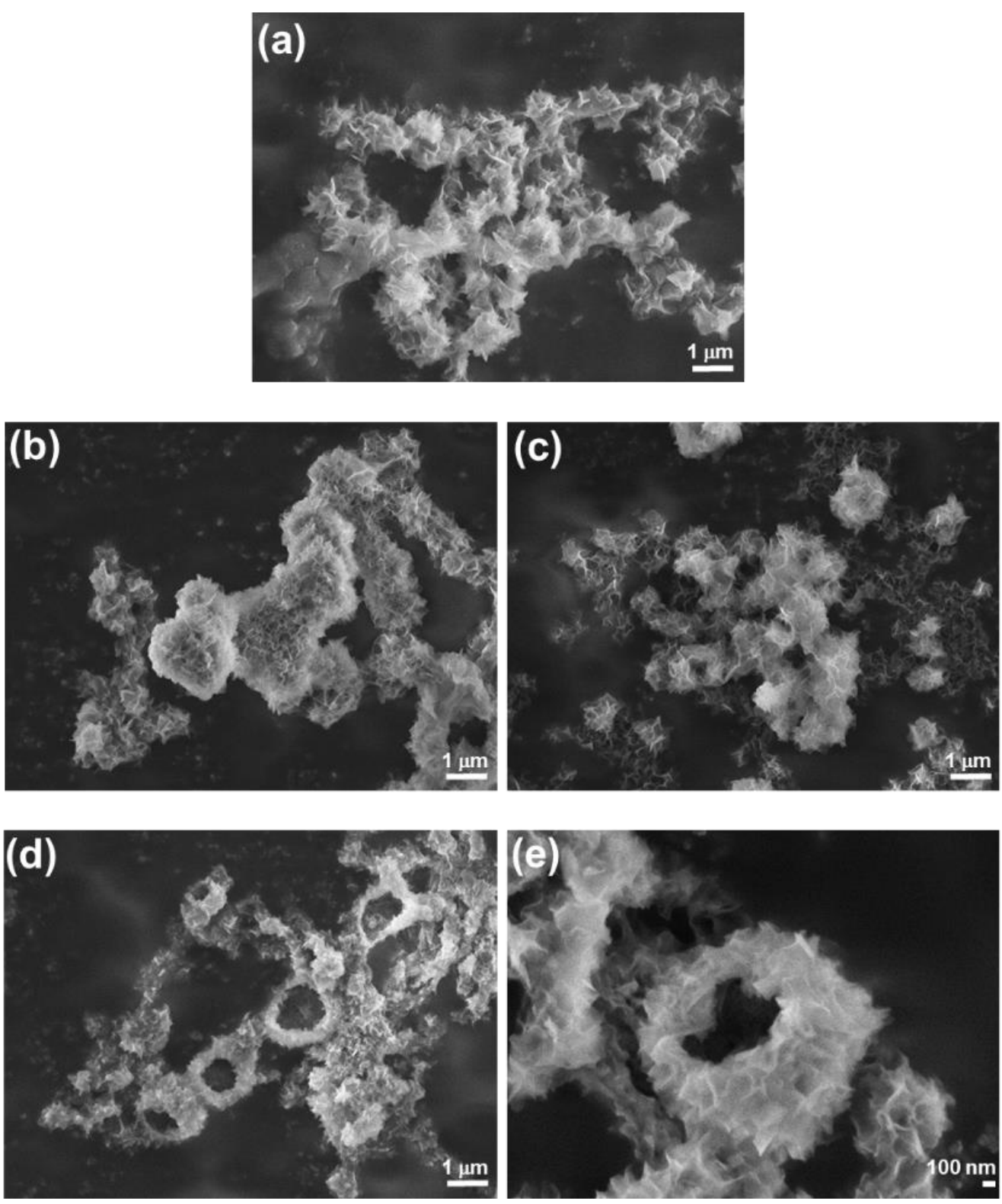

Figure 4. SEM micrographs of the precipitates formed after $60 \mathrm{~min}$ reaction time in the (a) absence (CS) and presence of different liposomes: (b) DMPC, (c) EPC, and (d,e) DMPS. $c_{\mathrm{i}}(\mathrm{Ca})=c_{\mathrm{i}}\left(\mathrm{PO}_{4}\right)=3.5 \mathrm{mmol} \mathrm{dm}{ }^{-3} ; \gamma($ lipid $)=25.0 \mathrm{ppm} ; \mathrm{pH}_{\mathrm{i}}=7.4 ; \vartheta /{ }^{\circ} \mathrm{C}=25 \pm 0.1$.

It seems that the ability of anionic lipids, in this specific case, DMPS, to concentrate and bind calcium ions $[79,80]$ could enable the formation of shell structures. Recent molecular dynamics simulations have shown that $\mathrm{Ca}^{2+}, \mathrm{HPO}_{4}^{2-}$ and PS complexes facilitate early nucleation [72]. It was also shown that zwitterionic PC liposomes could template CaP growth from $\mathrm{SBF}$ and that $\mathrm{CaP}$ hybrid nanostructured forms, differing in structure and morphology from CaDHA, appeared in the control system [47]. The morphology of CaP in the nanoshells prepared by the titration method depended on the type of anionic liposomes used for the template; i.e., the different sizes and zeta potentials of liposomes resulted in the formation of precipitates with different morphologies [31].

\subsection{Influence of the Liposomes on Precipitation of Calcium Carbonates}

The process of calcium carbonate precipitation in the presence of liposomes was investigated and compared to control systems containing no liposomes. In carbonate 
reactant solution, the sizes of DMPC and EPC liposomes were comparable to the sizes obtained in phosphate reactant solution, while the zeta potential of EPC liposomes was less positive. In contrast, the size of DMPS liposomes was larger in carbonate reactant solution, and the zeta potential was less positive (Table S4).

The progress of precipitation in the control system $\left(c_{\mathrm{i}}(\mathrm{Ca})=c_{\mathrm{i}}\left(\mathrm{CO}_{3}\right)=20 \mathrm{mmol} \mathrm{dm}^{-3}\right.$; $\mathrm{pH}_{\mathrm{i}}=8.15 ; \vartheta /{ }^{\circ} \mathrm{C}=(25 \pm 0.1)$ was followed by measuring the $\mathrm{pH}$ of the solution (Figure 5).

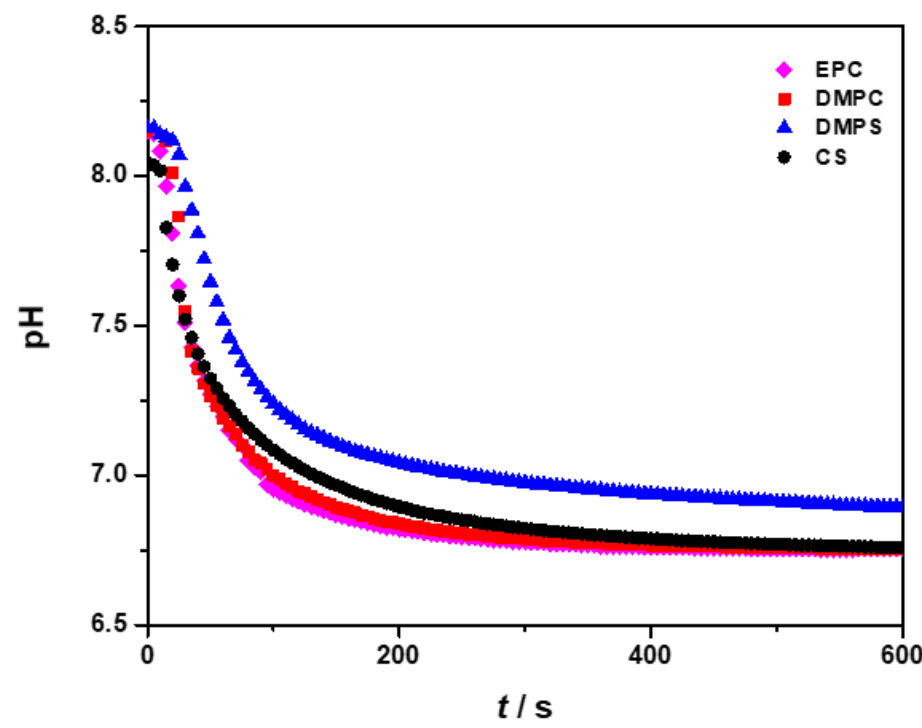

Figure 5. Representative $\mathrm{pH}$ vs. time curve during $\mathrm{CaCO}_{3}$ precipitation in the absence (CS) and presence of different lipids. $c_{\mathrm{i}}(\mathrm{Ca})=c_{\mathrm{i}}\left(\mathrm{CO}_{3}\right)=20 \mathrm{mmol} \mathrm{dm}{ }^{-3} \cdot \gamma($ lipid $)=25.0 \mathrm{ppm} ; \mathrm{pH}_{\mathrm{i}}=8.15$; $\vartheta /{ }^{\circ} \mathrm{C}=25 \pm 0.1$.

The solid phase appeared in the control system immediately after mixing the reactants, and $\mathrm{pH}$ decreased from about 8.15 to about 6.80 in less than $10 \mathrm{~min}$. Similar behavior of the precipitation system was noted when liposomes were added, thus indicating no significant influence on the induction time and progress of the precipitation process in the case of all EPC and DMPC concentrations and the case of lower DMPS concentrations (Figure S6). Representative $\mathrm{pH}$ vs. time curves obtained during $\mathrm{CaCO}_{3}$ precipitation in the presence of the highest applied lipid concentration, $\gamma$ (lipid) $=25.0$ ppm, are shown in Figure 5. For comparison, the progress curve of the control experiments, without the addition of liposomes, is also shown. It is obvious that the addition of EPC and DMPC did not significantly affect $\mathrm{CaCO}_{3}$ precipitation, while the addition of 25 ppm DMPS caused the termination of the process at a somewhat higher $\mathrm{pH}$ value compared to the control system (Figure 5). The likely explanation for the observed retardation of crystal growth is liposomes' adsorption on the crystal surface.

The mineral samples isolated from the control precipitation system, as well as those from the liposomal systems, 10 min after mixing the reactants, consisted of the unstable $\mathrm{CaCO}_{3}$ polymorph, vaterite, as determined from PXRD and FTIR analyses (band assignments in Tables S9-S12). A representative PXRD diffractogram and FTIR spectrum of the samples isolated from the control system are shown in Figure 6. The presence of vaterite was confirmed by the characteristic $020,021,022,130,114$, and 222 reflections at $24.9^{\circ}, 27.1^{\circ}$, $32.7^{\circ}, 43.8^{\circ}, 50.0^{\circ}$, and 55.8 $2 \theta$ (JCPDS: 33-0268), respectively. In comparison to the control system, the PXRD patterns of precipitates prepared in the presence of liposomes exhibit a somewhat higher peak intensity; the effect is more pronounced in DMPC and DMPS calcium carbonate systems (Figure S7). The FTIR spectrum (Figure 6b, band assignments in Table S9) was recorded in the region from 400 to $4000 \mathrm{~cm}^{-1}$, in which the characteristic absorbance band of vaterite, $v_{4}=746 \mathrm{~cm}^{-1}$, appeared [81,82]. For comparison, FTIR spectra (band assignments in Tables S9-S12) of samples isolated from the system with the highest lipid concentration are shown in Figure 7. The major differences can be observed in 
the region of $2700-3700 \mathrm{~cm}^{-1}$. Indeed, the EPC system (Figure 7a) shows no significant changes in comparison to the control system, while differences appear in the spectra of the samples precipitated in the presence of DMPC and DMPS liposomes. Representative FTIR spectra of precipitates isolated from systems with the addition of 25.0 ppm DMPC and DMPS liposomes are presented in Figure 7b,c. The principal bands (Figures S2-S4 and Tables S1-S3) between 2800 and $3000 \mathrm{~cm}^{-1}$ represent $\mathrm{CH}_{2}$ stretching modes, with the maxima of peaks at around $2851 \mathrm{~cm}^{-1}$ and around $2912 \mathrm{~cm}^{-1}$ corresponding to symmetric and asymmetric stretching in the $\mathrm{CH}_{2}$ groups of alkyl chains, with a minor contribution from symmetric and asymmetric stretching vibration in $\mathrm{CH}_{3}$ groups at around $2873 \mathrm{~cm}^{-1}$ and around $2955 \mathrm{~cm}^{-1}$, respectively [83]. Characteristic $\mathrm{CH}_{2}$ scissoring and $\mathrm{CH}_{2}$ bending (1420 and $1468 \mathrm{~cm}^{-1}$, respectively) overlap with strong carbonate ion normal vibrations (1500-1400 $\mathrm{cm}^{-1}$ ) [81]. In a $\mathrm{CaCO}_{3}$ crystallization study conducted by Beato et al. [51], vaterite became the only polymorph when zwitterionic DPPC was used in higher concentrations and at high supersaturations. The more hydrophobic environment obtained under these conditions corresponds to the formation of a complex, highly viscous sol network (i.e., micelles and reversed micelles) and vaterite formation inside aqueous confined spaces.
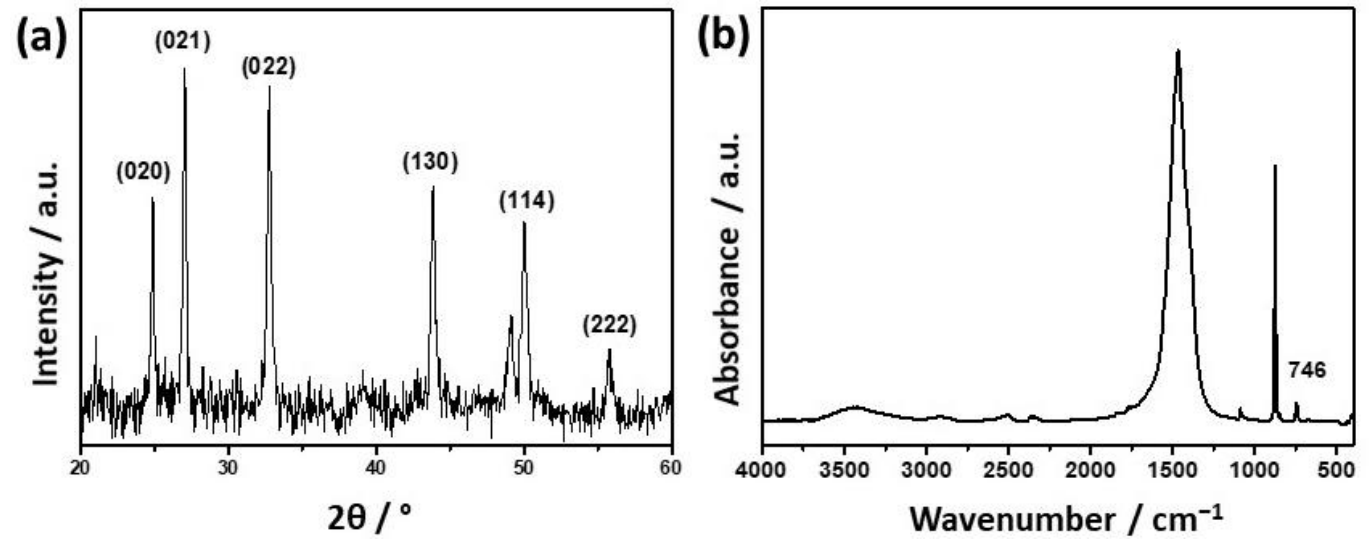

Figure 6. (a) PXRD pattern and (b) FTIR spectrum of precipitate, predominantly vaterite, isolated after $10 \mathrm{~min}$ of aging in the control system: $c_{\mathrm{i}}(\mathrm{Ca})=c_{\mathrm{i}}\left(\mathrm{CO}_{3}\right)=20 \mathrm{mmol} \mathrm{dm}{ }^{-3} ; \mathrm{pH}_{\mathrm{i}}=8.15 ; \vartheta /{ }^{\circ} \mathrm{C}=25 \pm 0.1$.

The content of organic material in vaterite samples was estimated by conducting thermogravimetric analysis. It was found that the decomposition of samples prepared in the presence of liposomes occurred in two steps, while for the sample prepared in the absence of liposomes, only one decomposition step was observed. Thus, Figure 8 shows TGA curves of samples prepared in the presence of the highest concentration of different liposomes: the weight loss in the temperature range between 200 and $500{ }^{\circ} \mathrm{C}$ corresponds to the decomposition of liposomes, while the decomposition of $\mathrm{CaCO}_{3}$ to $\mathrm{CaO}$ and $\mathrm{CO}_{2}$ occurs at about $800{ }^{\circ} \mathrm{C}$. It was found that the TG curve of the sample isolated from the system with the addition of EPC shows no significant changes compared to the TG curve of the control system. However, a mass loss at about $350^{\circ} \mathrm{C}$ was observed in the case of samples prepared in the presence of DMPC and DMPS liposomes. The estimated maximum value of organic content in those samples was 7.2\% for the DMPC sample and $9.7 \%$ for the DMPS sample. The results are consistent with the respective FTIR analysis and confirm the presence of DMPC or DMPS in the vaterite crystals. Previous studies reported the incorporation of organic species in biomimetic calcite and vaterite [84-86], while a much higher lipid content, about 30\%, was detected in amorphous calcium carbonate particles [87]. Gopal and co-workers reported the synthesis of calcium carbonate microparticles with phospholipids entrapped (2.5-5.0\%) in the porous vaterite structure, resulting in an organic/inorganic complex matrix [45]. Their TG analysis revealed that calcium carbonate and phospholipids in these microparticles exhibit strong interactions. 


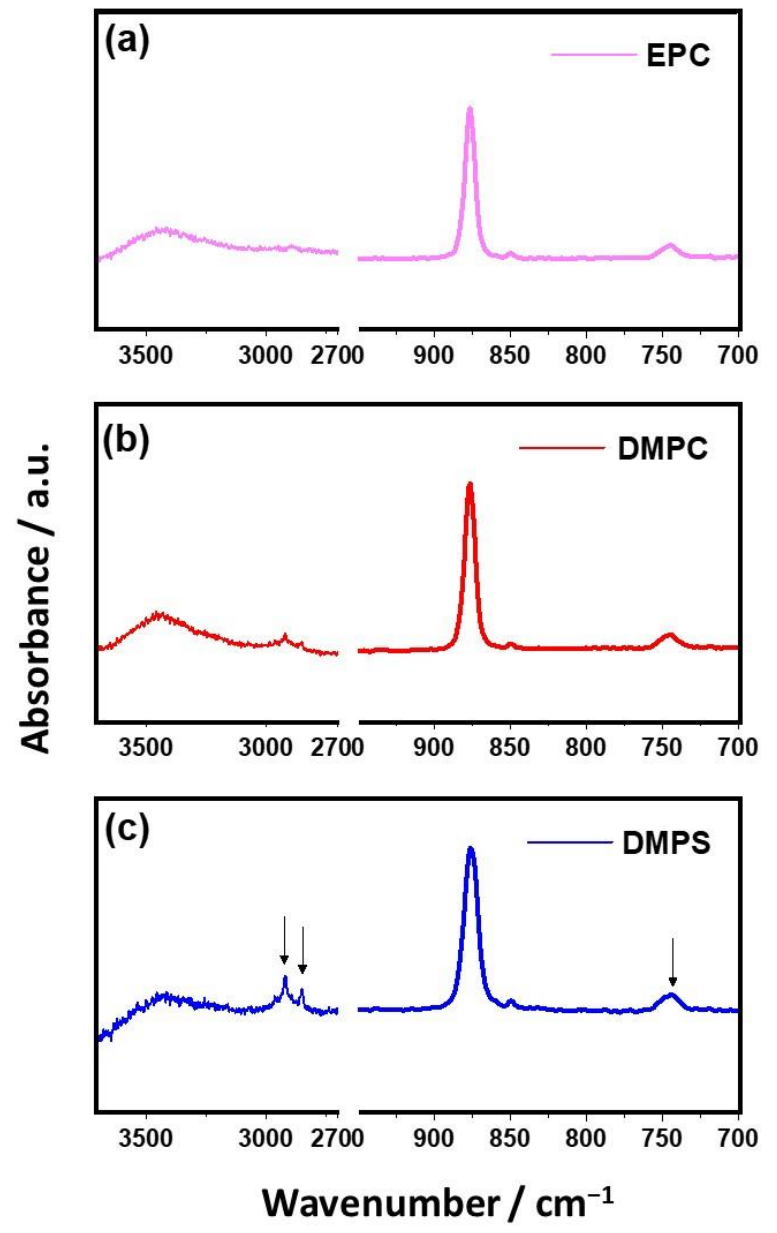

Figure 7. FTIR spectra of vaterite formed after $10 \mathrm{~min}$ of aging time in systems with the presence of different liposomes: (a) EPC, (b) DMPC, and (c) DMPS; $c_{\mathrm{i}}(\mathrm{Ca})=c_{\mathrm{i}}\left(\mathrm{CO}_{3}\right)=20 \mathrm{mmol} \mathrm{dm}^{-3}$; $\gamma($ lipid $)=25.0 \mathrm{ppm} ; \mathrm{pH}_{\mathrm{i}}=8.15 ; \vartheta /{ }^{\circ} \mathrm{C}=25 \pm 0.1$. Arrows: characteristic absorbance band of vaterite, $746 \mathrm{~cm}^{-1}$, and characteristic $\mathrm{CH}_{2}$ stretching modes of liposome, $2851 \mathrm{~cm}^{-1}$ and $2912 \mathrm{~cm}^{-1}$.

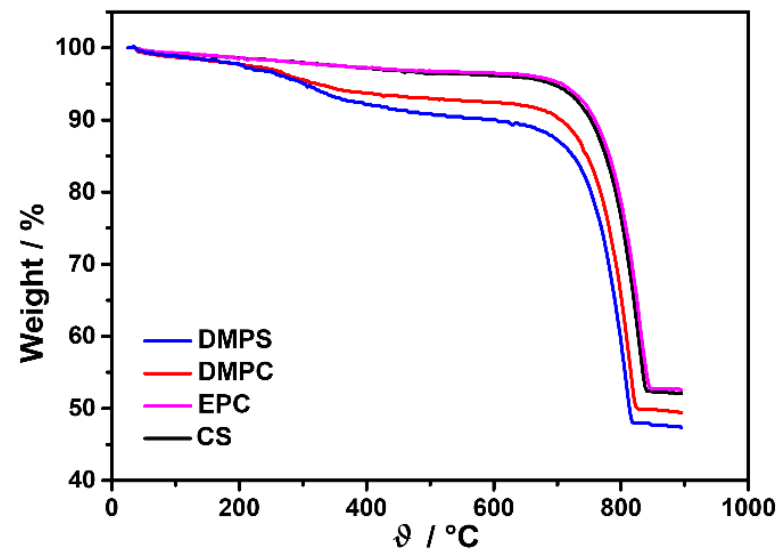

Figure 8. Thermogravimetric analysis of sample formed after $10 \mathrm{~min}$ of aging time in the absence (CS) and presence of different liposomes. $c_{\mathrm{i}}(\mathrm{Ca})=c_{\mathrm{i}}\left(\mathrm{CO}_{3}\right), \gamma($ lipid $)=25.0 \mathrm{ppm}, \mathrm{pH}_{\mathrm{i}}=8.15, \vartheta /{ }^{\circ} \mathrm{C}=25 \pm 0.1$.

SEM micrographs of the sample precipitated in the control system (Figure 9a) showed predominantly 2.0-2.5 $\mu \mathrm{m}$ spherical and some plate-like particles with a rough surface. These particles are the aggregates of primary particles, with an average size of $\leq 50 \mathrm{~nm}$, which is characteristic of vaterite [88]. The samples obtained in the presence of liposomes contained spherical or plate-like particles that were larger $(2-5 \mu \mathrm{m})$ with different aggre- 
gation and surface structures (Figure $9 \mathrm{~b}-\mathrm{d}$ ). The literature reports vaterite particles with a mean size of $5 \pm 2 \mu \mathrm{m}$ prepared in the presence of negatively charged phospholipid mixtures of negative and zwitterionic phospholipids [45]. The strongest influence on the vaterite morphology was found after the addition of negatively charged DMPS. The SEM image in Figure 9d shows that vaterite particles are superstructures of crossed disc-shaped forms, having a uniform thickness of about $10 \mathrm{~nm}$. The observed effect on morphology can be correlated with FTIR and TG results (Figures 7 and 8), which show that liposomes interact with the calcium carbonate surface. The interactions probably occurred between calcium ions on the surfaces and carbonyl, phosphate, and carboxylate groups of the phospholipids [48]. DMPS, in comparison to DMPC and EPC, has more potent calcium-binding sites, which may cause crystal growth suppression in a specific direction, which in turn leads to anisotropic growth of the crystal and the formation of novel superstructures. SEM micrographs of precipitate formed in the presence of DMPS also revealed some vaterite spheres with void structures (hollow aggregates) (Figure 9e). The occurrence of differently textured vaterite crystals obtained in lecithin-templated calcium carbonate crystallization under a continuous $\mathrm{CO}_{2}$ diffusion atmosphere [51] reflects the geometry and spatial distribution of aqueous constrained spaces due to lecithin assembly, controlled by lecithin concentration, in calcium chloride solution.
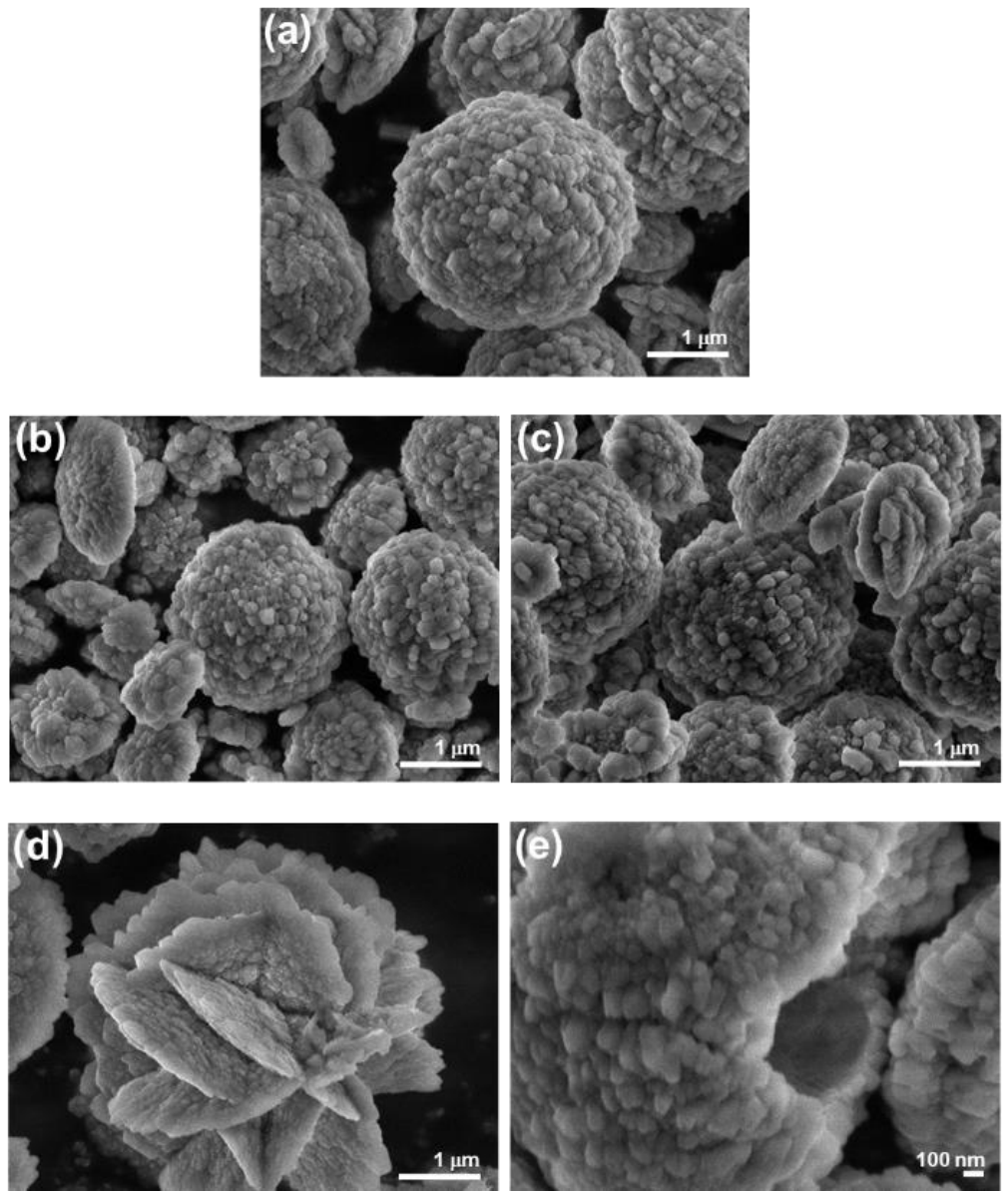

Figure 9. SEM micrographs of vaterite precipitated after $10 \mathrm{~min}$ of aging time in the (a) absence (CS) and presence of different liposomes: $\operatorname{EPC}(\mathbf{b}), \operatorname{DMPC}(\mathbf{c})$, and DMPS $(\mathbf{d}, \mathbf{e}) \cdot c_{\mathrm{i}}(\mathrm{Ca})=c_{\mathrm{i}}\left(\mathrm{CO}_{3}\right)=20 \mathrm{mmol} \mathrm{dm}^{-3}$; $\gamma($ lipid $)=25.0 \mathrm{ppm} ; \mathrm{pH}_{\mathrm{i}}=8.15 ; \vartheta /{ }^{\circ} \mathrm{C}=25 \pm 0.1$.

\subsection{Comparison of the Liposomes' Influence on $\mathrm{CaP}$ and $\mathrm{CaCO}_{3}$ Precipitation}

The majority of the studies of $\mathrm{CaP}$ and $\mathrm{CaCO}_{3}$ precipitation in the presence of liposomes were conducted using liposomes containing one or both reactant solutions $[38,89,90]$ or by preparing liposomes coated with an inorganic phase by titration $[14,31,45]$. Sur- 
prisingly, investigations of spontaneous precipitation in the presence of liposomes are scarce $[33,36,50,91]$. However, spontaneous precipitation, in addition to its role in investigating biomineralization, can be used as a fast and versatile method of preparation of materials with specific properties that are tailored by experimental conditions, including the presence of additives [92].

Despite the intrinsic difference in the investigated precipitation systems, including differences in the size and charge of the liposomes, the obtained results indicate that their effects on the precipitation of $\mathrm{CaP}$ and $\mathrm{CaCO}_{3}$ share some common features.

In both control precipitation systems, the precipitation started immediately upon the mixing of the reactants. In the CaP system, the first formed solid phase was $\mathrm{ACP}$, which transformed into $\mathrm{CaDHA}$. In the $\mathrm{CaCO}_{3}$ system, vaterite was the initially formed solid, which did not transform during the investigated aging period. Liposomes did not influence the composition of the formed precipitates. However, in the case of $\mathrm{CaP}$, they did influence the rate of ACP transformation to CaDHA. Thus, in the presence of zwitterionic DMPC liposomes, the ACP transformation was retarded, while in the presence of negatively charged DMPS liposomes, it was promoted. On the other hand, in the $\mathrm{CaCO}_{3}$ system, in the presence of the highest investigated concentration of DMPS liposomes, retardation of crystal growth was observed. Previous studies have shown that liposomes, whose composition corresponded to that of matrix vesicle membranes, are not able to induce precipitation from a metastable solution containing $2.25 \mathrm{mM} \mathrm{Ca}^{2+}$ and $1.50 \mathrm{mM}$ inorganic phosphate [50]. However, phosphatidylcholine liposomes were able to induce the formation of ACP in SBF [47]. In the presence of lecithin [36] and dipalmitoylphosphatidylcholine [33] liposomes at concentrations higher than those used in this study, the influence of liposomes on the composition and morphology of $\mathrm{CaCO}_{3}$ precipitate was concentration-dependent. The observed effects were attributed to the ability of negatively charged head groups to concentrate $\mathrm{Ca}^{2+}$ ions, facilitating nucleation and modifying crystal growth $[35,36,47]$, which is in accordance with our results showing that negatively charged DMPS has the most pronounced effect.

The most interesting result of this study is the formation of both CaDHA and vaterite (nano) shells/hollow spheres in the presence of the highest investigated concentration of DMPS. This could be attributed to the high affinity of negatively charged phosphatidylserine moiety towards $\mathrm{Ca}^{2+}$ ions [72]. Until now, shell structures were usually obtained by more complex and longer-lasting titration procedures [14,31,45].

The obtained results confirm the literature data on the importance of phospholipid head group arrangement and interactions with both mineral surfaces $[35,38]$.

\section{Conclusions}

In this work, the influence of differently charged and sized liposomes on $\mathrm{CaP}$ and $\mathrm{CaCO}_{3}$ precipitation in aqueous solutions supersaturated with respect to relevant solid phases was investigated. When compared to the respective control systems, the mineralogical composition of both $\mathrm{CaP}$ and $\mathrm{CaCO}_{3}$ precipitates formed was not affected by the presence of liposomes. On the other hand, liposomes influenced both the precipitation and transformation kinetics and the morphology of $\mathrm{CaP}$ and $\mathrm{CaCO}_{3}$ precipitated phases. In both precipitation systems, it was shown that DMPS liposomes exerted the most noticeable influence on morphology; either CaDHA or vaterite (nano) shells/hollow spheres were formed, which could be explained by specific electrostatic interactions between phosphatidylserine and $\mathrm{Ca}^{2+}$ ions present on mineral surfaces.

The results also confirm that, despite differences in the chemical composition, solubility, and/or stabilities of the phospholipids used herein, similarities in the mechanisms of the formation of the biominerals calcium phosphates and calcium carbonates exist. However, both biomimetic precipitation systems need to be more thoroughly and methodically investigated and compared to systematically establish new synthetic routes for the preparation of functional materials that are applicable in different fields. 
Supplementary Materials: The following are available online at https: / / www.mdpi.com/article/ $10.3390 / \min 12020208 / s 1$, Figure S1. Molecular structure of the lipids used in this study for the preparation of liposomes with different surface charges. Figure S2. FTIR spectra of 1,2-dimyristoyl-snglycero-3-phosphocholine (DMPC). Figure S3. FTIR spectra of 1,2-dimyristoyl-sn-glycero-3-phosphoL-serine (DMPS). Figure S4. FTIR spectra of 1,2-dioleoyl-sn-glycero-3-ethylphosphocholine (EPC). Figure S5. TEM micrographs and size distribution of ACP particles formed in control system and in the presence of DMPC and DMPS liposomes in spontaneous precipitation experiment. Figure S6. Representative $\mathrm{pH}$ vs. time curve of $\mathrm{CaCO}_{3}$ spontaneous precipitation experiments. Figure S7. PXRD patterns of the precipitate formed after 60 min reaction time in $\mathrm{CaCO}_{3}$ spontaneous precipitation experiments. Table S1. Assignment of IR bands in the FTIR spectra of 1,2-dimyristoyl-sn-glycero-3phosphocholine (DMPC). Table S2. Assignment of IR bands in the FTIR spectra of 1,2-dimyristoylsn-glycero-3-phospho-L-serine (DMPS). Table S3. Assignment of IR bands in the FTIR spectra of 11,2-dioleoyl-sn-glycero-3-ethylphosphocholine (EPC). Table S4. Hydrodynamic diameter $\left(d_{\mathrm{h}}\right)$ and zeta potential $(\zeta)$ of liposomes. Table S5. Assignment of IR bands in the FTIR spectra of precipitate formed after $60 \mathrm{~min}$ in calcium phosphate control system. Table S6. Assignment of IR bands in the FTIR spectra of precipitate formed after $60 \mathrm{~min}$ in calcium phosphate system containing DMPC liposomes. Table S7. Assignment of IR bands in the FTIR spectra of precipitate formed after $60 \mathrm{~min}$ in calcium phosphate system containing DMPS liposomes. Table S8. Assignment of IR bands in the FTIR spectra of precipitate formed after $60 \mathrm{~min}$ in calcium phosphate system containing EPC liposomes. Table S9. Assignment of IR bands in the FTIR spectra of precipitate formed after $60 \mathrm{~min}$ in calcium carbonate control system. Table S10. Assignment of IR bands in the FTIR spectra of precipitate formed in calcium carbonate system containing DMPC liposomes. Table S11. Assignment of IR bands in the FTIR spectra of precipitate formed in calcium carbonate system containing DMPS liposomes. Table S12. Assignment of IR bands in the FTIR spectra of precipitate formed in calcium carbonate system containing EPC liposomes.

Author Contributions: Conceptualization, M.D.S. and D.K.; methodology, I.E., J.K., V.S., M.D.S. and D.K.; formal analysis, I.E., J.K., V.S., M.D.S. and D.K.; investigation, I.E., J.K., V.S., A.S., D.D.J., M.Ć., B.N.D., N.M.M., S.Š. and D.M.L.; resources, M.D.S. and D.K.; writing-original draft preparation, J.K., M.D.S. and D.K.; writing-review and editing, J.K., M.D.S. and D.K.; visualization, V.S.; funding acquisition, M.D.S. and D.K. All authors have read and agreed to the published version of the manuscript.

Funding: This work has been financially supported by the Croatian Science Foundation under projects HrZZ-IP-2013-11-5055 and HRZZ-IP-2018-01-1493.

Data Availability Statement: The data are available within the article or its supplementary materials.

Conflicts of Interest: There are no conflict to declare.

\section{References}

1. Falini, G.; Fermani, S. The Strategic Role of Adsorption Phenomena in Biomineralization: Biomineralization. Cryst. Res. Technol. 2013, 48, 864-876. [CrossRef]

2. Lowenstam, H.A.; Weiner, S. On Biomineralization; Oxford University Press: New York, NY, USA, 1989; ISBN 978-0-19-504977-0.

3. Collier, J.H.; Messersmith, P.B. Phospholipid Strategies in Biomineralization and Biomaterials Research. Annu. Rev. Mater. Res. 2001, 31, 237-263. [CrossRef]

4. Boonrungsiman, S.; Gentleman, E.; Carzaniga, R.; Evans, N.D.; McComb, D.W.; Porter, A.E.; Stevens, M.M. The Role of Intracellular Calcium Phosphate in Osteoblast-Mediated Bone Apatite Formation. Proc. Natl. Acad. Sci. USA 2012, 109, 14170-14175. [CrossRef] [PubMed]

5. Weiner, S.; Addadi, L. Crystallization Pathways in Biomineralization. Annu. Rev. Mater. Res. 2011, 41, 21-40. [CrossRef]

6. Ansari, S.; de Wildt, B.W.M.; Vis, M.A.M.; de Korte, C.E.; Ito, K.; Hofmann, S.; Yuana, Y. Matrix Vesicles: Role in Bone Mineralization and Potential Use as Therapeutics. Pharmaceuticals 2021, 14, 289. [CrossRef]

7. Guibert, C.; Landoulsi, J. Enzymatic Approach in Calcium Phosphate Biomineralization: A Contribution to Reconcile the Physicochemical with the Physiological View. Int. J. Mol. Sci. 2021, 22, 12957. [CrossRef]

8. Young, J.R.; Didymus, J.M.; Brown, P.R.; Prins, B.; Mann, S. Crystal Assembly and Phylogenetic Evolution in Heterococcoliths. Nature 1992, 356, 516. [CrossRef]

9. Golub, E.E. Role of Matrix Vesicles in Biomineralization. Biochim. Biophys. Acta-Gen. Subj. 2009, 1790, 1592-1598. [CrossRef]

10. Komeili, A. Molecular Mechanisms of Compartmentalization and Biomineralization in Magnetotactic Bacteria. FEMS Microbiol. Rev. 2012, 36, 232-255. [CrossRef] 
11. Tester, C.C.; Joester, D. Precipitation in Liposomes as a Model for Intracellular Biomineralization. In Methods in Enzymology; Elsevier: Amsterdam, The Netherlands, 2013; Volume 532, pp. 257-276, ISBN 978-0-12-416617-2.

12. Favarin, B.Z.; Bolean, M.; Ramos, A.P.; Magrini, A.; Rosato, N.; Millan, J.L.; Bottini, M.; Costa-Filho, A.J.; Ciancaglini, P. Lipid Composition Modulates ATP Hydrolysis and Calcium Phosphate Mineral Propagation by TNAP-Harboring Proteoliposomes. Arch. Biochem. Biophys. 2020, 691, 108482. [CrossRef]

13. Qi, C.; Musetti, S.; Fu, L.-H.; Zhu, Y.-J.; Huang, L. Biomolecule-Assisted Green Synthesis of Nanostructured Calcium Phosphates and Their Biomedical Applications. Chem. Soc. Rev. 2019, 48, 2698-2737. [CrossRef] [PubMed]

14. Bewernitz, M.A.; Lovett, A.C.; Gower, L.B. Liquid-Solid Core-Shell Microcapsules of Calcium Carbonate Coated Emulsions and Liposomes. Appl. Sci. 2020, 10, 8551. [CrossRef]

15. Šegota, S.; Vojta, D.; Pletikapić, G.; Baranović, G. Ionic Strength and Composition Govern the Elasticity of Biological Membranes. A Study of Model DMPC Bilayers by Force- and Transmission IR Spectroscopy. Chem. Phys. Lipids 2015, 186, 17-29. [CrossRef]

16. Guimarães, D.; Cavaco-Paulo, A.; Nogueira, E. Design of Liposomes as Drug Delivery System for Therapeutic Applications. Int J. Pharm. 2021, 601, 120571. [CrossRef]

17. Song, J.; Wang, R.; Liu, Z.; Zhang, H. Preparation and Characterization of Calcium Carbonate Microspheres and Their Potential Application as Drug Carriers. Mol. Med. Rep. 2018, 17, 8403-8408. [CrossRef] [PubMed]

18. Wang, L.; Nancollas, G.H. Calcium Orthophosphates: Crystallization and Dissolution. Chem. Rev. 2008, 108, 4628-4669. [CrossRef]

19. Dorozhkin, S.V. Calcium Orthophosphates: Applications in Nature, Biology, and Medicine; CRC Press: Boca Raton, FL, USA, 2012; ISBN 978-981-4364-17-1.

20. Dorozhkin, S.V.; Epple, M. Biological and Medical Significance of Calcium Phosphates. Angew. Chem. Int. Ed. 2002, 41, 3130-3146. [CrossRef]

21. Erdogan, N.; Eken, H.A. Precipitated Calcium Carbonate Production, Synthesis and Properties. Physicochem. Probl. Miner. Process. 2017, 57, 57-68. [CrossRef]

22. Amjad, Z. (Ed.) Calcium Phosphates in Biological and Industrial Systems; Springer: New York, NY, USA, 1998; ISBN 978-0-7923-8046-7.

23. Sikirić, M.D.; Füredi-Milhofer, H. The Influence of Surface Active Molecules on the Crystallization of Biominerals in Solution. Adv. Colloid Interface Sci. 2006, 128-130, 135-158. [CrossRef]

24. Omelon, S.J.; Grynpas, M.D. Relationships between Polyphosphate Chemistry, Biochemistry and Apatite Biomineralization. Chem. Rev. 2008, 108, 4694-4715. [CrossRef]

25. Rey, C.; Combes, C.; Drouet, C.; Sfihi, H. Chemical Diversity of Apatites. Adv. Sci. Technol. 2006, 49, 27-36. [CrossRef]

26. Falini, G.; Albeck, S.; Weiner, S.; Addadi, L. Control of Aragonite or Calcite Polymorphism by Mollusk Shell Macromolecules. Science 1996, 271, 67-69. [CrossRef]

27. Njegić-Džakula, B.; Brečević, L.; Falini, G.; Kralj, D. Calcite Crystal Growth Kinetics in the Presence of Charged Synthetic Polypeptides. Cryst. Growth Des. 2009, 9, 2425-2434. [CrossRef]

28. Štajner, L.; Kontrec, J.; Njegić Džakula, B.; Maltar-Strmečki, N.; Plodinec, M.; Lyons, D.M.; Kralj, D. The Effect of Different Amino Acids on Spontaneous Precipitation of Calcium Carbonate Polymorphs. J. Cryst. Growth 2018, 486, 71-81. [CrossRef]

29. Mann, S. Biomineralization: Principles and Concepts in Bioinorganic Materials Chemistry; Oxford University Press: New York, NY, USA, 2001; ISBN 978-0-19-850882-3.

30. Chai, Y.; Yamaguchi, T.; Tagaya, M. Fabrication of Phospholipid Vesicle-Interacted Calcium Phosphate Films with Sterilization Stability. Cryst. Growth Des. 2017, 17, 4977-4983. [CrossRef]

31. Yeo, C.-H.; Zein, S.H.S.; Ahmad, A.L.; McPhail, D.S. Comparison of DOPA and DPPA Liposome Templates for the Synthesis of Calcium Phosphate Nanoshells. Ceram. Int. 2012, 38, 561-570. [CrossRef]

32. Schmidt, H.T.; Ostafin, A.E. Liposome Directed Growth of Calcium Phosphate Nanoshells. Adv. Mater. 2002, 14, 532-535. [CrossRef]

33. Szcześ, A.; Sternik, D. Properties of Calcium Carbonate Precipitated in the Presence of DPPC Liposomes Modified with the Phospholipase A2. J. Therm. Anal. Calorim. 2016, 123, 2357-2365. [CrossRef]

34. Gong, J.; Zhou, Z.; Hu, X.; Wong, M.; Wong, K.; Du, Z. Self-Assembled Chitosan Nanotemplates for Biomineralization of Controlled Calcite Nanoarchitectures. ACS Appl. Mater. Interfaces 2009, 1, 26-29. [CrossRef]

35. Szcześ, A. Effects of DPPC/Cholesterol Liposomes on the Properties of Freshly Precipitated Calcium Carbonate. Colloids Surf. B Biointerfaces 2013, 101, 44-48. [CrossRef]

36. Wan, P.; Zhao, Y.; Tong, H.; Yang, Z.; Zhu, Z.; Shen, X.; Hu, J. The Inducing Effect of Lecithin Liposome Organic Template on the Nucleation and Crystal Growth of Calcium Carbonate. Mater. Sci. Eng. C 2009, 29, 222-227. [CrossRef]

37. Eanes, E.D.; Hailer, A.W.; Costa, J.L. Calcium Phosphate Formation in Aqueous Suspensions of Multilamellar Liposomes. Calcif. Tissue Int. 1984, 36, 421-430. [CrossRef]

38. Heywood, B.R.; Eanes, E.D. An Ultrastructural Study of the Effects of Acidic Phospholipid Substitutions on Calcium Phosphate Precipitation in Anionic Liposomes. Calcif. Tissue Int. 1992, 50, 149-156. [CrossRef] [PubMed]

39. Feng, Q.L.; Chen, Q.H.; Wang, H.; Cui, F.Z. Influence of Concentration of Calcium Ion on Controlled Precipitation of Calcium Phosphate within Unilamellar Lipid Vesicles. J. Cryst. Growth 1998, 186, 245-250. [CrossRef]

40. Messersmith, P.B.; Vallabhaneni, S.; Nguyen, V. Preparation of Calcium-Loaded Liposomes and Their Use in Calcium Phosphate Formation. Chem. Mater. 1998, 10, 109-116. [CrossRef] 
41. Ramedani, A.; Yazdanpanah, A.; Moztarzadeh, F.; Mozafari, M. On the Use of Nanoliposomes as Soft Templates for Controlled Nucleation and Growth of Hydroxyapatite Nanocrystals under Hydrothermal Conditions. Ceram. Int. 2014, 40, 9377-9381. [CrossRef]

42. Chen, W.-Y.; Yang, C.-I.; Lin, C.-J.; Huang, S.-J.; Chan, J.C.C. Characterization of the Crystallization Pathway of Calcium Phosphate in Liposomes. J. Phys. Chem. C 2014, 118, 12022-12027. [CrossRef]

43. Tester, C.C.; Brock, R.E.; Wu, C.-H.; Krejci, M.R.; Weigand, S.; Joester, D. In Vitro Synthesis and Stabilization of Amorphous Calcium Carbonate (ACC) Nanoparticles within Liposomes. CrystEngComm 2011, 13, 3975. [CrossRef]

44. Tester, C.C.; Whittaker, M.L.; Joester, D. Controlling Nucleation in Giant Liposomes. Chem. Commun. 2014, 50, 5619-5622. [CrossRef]

45. Gopal, K.; Lu, Z.; de Villiers, M.M.; Lvov, Y. Composite Phospholipid-Calcium Carbonate Microparticles: Influence of Anionic Phospholipids on the Crystallization of Calcium Carbonate. J. Phys. Chem. B 2006, 110, 2471-2474. [CrossRef]

46. Rivero Berti, I.; Dell' Arciprete, M.L.; Dittler, M.L.; Miñan, A.; de Mele, M.F.L.; Gonzalez, M. Delivery of Fluorophores by Calcium Phosphate-Coated Nanoliposomes and Interaction with Staphylococcus Aureus Biofilms. Colloids Surf. B Biointerfaces 2016, 142, 214-222. [CrossRef] [PubMed]

47. Tagaya, M.; Yamaguchi, T.; Shiba, K. Preparation of Phospholipid Vesicle-Templated Calcium Phosphate Nanostructures and Their Cytocompatibility. Cryst. Growth Des. 2016, 16, 2843-2849. [CrossRef]

48. Fukui, Y.; Fujimoto, K. Control in Mineralization by the Polysaccharide-Coated Liposome via the Counter-Diffusion of Ions. Chem. Mater. 2011, 23, 4701-4708. [CrossRef]

49. Nguyen, S.; Solheim, L.; Bye, R.; Rykke, M.; Hiorth, M.; Smistad, G. The Influence of Liposomal Formulation Factors on the Interactions between Liposomes and Hydroxyapatite. Colloids Surf. B Biointerfaces 2010, 76, 354-361. [CrossRef]

50. Skrtic, D.; Eanes, E.D. Membrane-Mediated Precipitation of Calcium Phosphate in Model Liposomes with Matrix Vesicle-like Lipid Composition. Bone Miner. 1992, 16, 109-119. [CrossRef]

51. Beato, C.; Fernández, M.S.; Fermani, S.; Reggi, M.; Neira-Carrillo, A.; Rao, A.; Falini, G.; Arias, J.L. Calcium Carbonate Crystallization in Tailored Constrained Environments. CrystEngComm 2015, 17, 5953-5961. [CrossRef]

52. Buljan Meić, I.; Kontrec, J.; Domazet Jurašin, D.; Selmani, A.; Njegić Džakula, B.; Maltar-Strmečki, N.; Lyons, D.M.; Plodinec, M.; Čeh, M.; Gajović, A.; et al. How Similar Are Amorphous Calcium Carbonate and Calcium Phosphate? A Comparative Study of Amorphous Phase Formation Conditions. CrystEngComm 2018, 20, 35-50. [CrossRef]

53. Buljan Meić, I.; Kontrec, J.; Domazet Jurašin, D.; Njegić Džakula, B.; Štajner, L.; Lyons, D.M.; Dutour Sikirić, M.; Kralj, D Comparative Study of Calcium Carbonates and Calcium Phosphates Precipitation in Model Systems Mimicking the Inorganic Environment for Biomineralization. Cryst. Growth Des. 2017, 17, 1103-1117. [CrossRef]

54. Addadi, L.; Joester, D.; Nudelman, F.; Weiner, S. Mollusk Shell Formation: A Source of New Concepts for Understanding Biomineralization Processes. Chem.-A Eur. J. 2006, 12, 980-987. [CrossRef]

55. Dorozhkin, S.V. Calcium Orthophosphates. Application in Nature, Biology and Medicine. Materials 2012, 2, 399-498. [CrossRef]

56. Kahil, K.; Weiner, S.; Addadi, L.; Gal, A. Ion Pathways in Biomineralization: Perspectives on Uptake, Transport, and Deposition of Calcium, Carbonate, and Phosphate. J. Am. Chem. Soc. 2021, 143, 21100-21112. [CrossRef] [PubMed]

57. Bentov, S.; Weil, S.; Glazer, L.; Sagi, A.; Berman, A. Stabilization of Amorphous Calcium Carbonate by Phosphate Rich Organic Matrix Proteins and by Single Phosphoamino Acids. J. Struct. Biol. 2010, 171, 207-215. [CrossRef]

58. Zou, Z.; Polishchuk, I.; Bertinetti, L.; Pokroy, B.; Politi, Y.; Fratzl, P.; Habraken, W.J.E.M. Additives Influence the Phase Behavior of Calcium Carbonate Solution by a Cooperative Ion-Association Process. J. Mater. Chem. B 2018, 6, 449-457. [CrossRef] [PubMed]

59. Onoda, H.; Yamazaki, S. Homogenous Hydrothermal Synthesis of Calcium Phosphate with Calcium Carbonate and Corbicula Shells. J. Asian Ceram. Soc. 2016, 4, 403-406. [CrossRef]

60. Cestari, F.; Agostinacchio, F.; Galotta, A.; Chemello, G.; Motta, A.; Sglavo, V.M. Nano-Hydroxyapatite Derived from Biogenic and Bioinspired Calcium Carbonates: Synthesis and In Vitro Bioactivity. Nanomaterials 2021, 11, 264. [CrossRef] [PubMed]

61. Bleek, K.; Taubert, A. New Developments in Polymer-Controlled, Bioinspired Calcium Phosphate Mineralization from Aqueous Solution. Acta Biomater. 2013, 9, 6283-6321. [CrossRef]

62. Bar-Yosef Ofir, P.; Govrin-Lippman, R.; Garti, N.; Füredi-Milhofer, H. The Influence of Polyelectrolytes on the Formation and Phase Transformation of Amorphous Calcium Phosphate. Cryst. Growth Des. 2004, 4, 177-183. [CrossRef]

63. Brečević, L.; Füredi-Milhofer, H. Precipitation of Calcium Phosphates from Electrolyte Solutions: II. The Formation and Transformation of the Precipitates. Calcif. Tissue Res. 1972, 10, 82-90. [CrossRef] [PubMed]

64. Eans, E.D.; Gillessen, I.H.; Posner, A.S. Intermediate States in the Precipitation of Hydroxyapatite. Nature 1965, $208,365-367$. [CrossRef]

65. Selmani, A.; Coha, I.; Magdić, K.; Čolović, B.; Jokanović, V.; Šegota, S.; Gajović, S.; Gajović, A.; Jurašin, D.; Dutour Sikirić, M. Multiscale Study of the Influence of Cationic Surfactants on Amorphous Calcium Phosphate Precipitation. CrystEngComm 2015, 17, 8529-8548. [CrossRef]

66. Ding, H.; Pan, H.; Xu, X.; Tang, R. Toward a Detailed Understanding of Magnesium Ions on Hydroxyapatite Crystallization Inhibition. Cryst. Growth Des. 2014, 14, 763-769. [CrossRef]

67. Despotović, R.; Filipović-Vinceković, N.; Füredi-Milhofer, H. Precipitation of Calcium Phosphates from Electrolyte Solutions. Calcif. Tissue Res. 1975, 18, 13-26. [CrossRef] 
68. Wang, C.-G.; Liao, J.-W.; Gou, B.-D.; Huang, J.; Tang, R.-K.; Tao, J.-H.; Zhang, T.-L.; Wang, K. Crystallization at Multiple Sites inside Particles of Amorphous Calcium Phosphate. Cryst. Growth Des. 2009, 9, 2620-2626. [CrossRef]

69. Li, S.; Wang, L. Phosphorylated Osteopontin Peptides Inhibit Crystallization by Resisting the Aggregation of Calcium Phosphate Nanoparticles. CrystEngComm 2012, 14, 8037. [CrossRef]

70. Chen, Y.; Gu, W.; Pan, H.; Jiang, S.; Tang, R. Stabilizing Amorphous Calcium Phosphate Phase by Citrate Adsorption. CrystEngComm 2014, 16, 1864-1867. [CrossRef]

71. Wuthier, R.E.; Eanes, E.D. Effect of Phospholipids on the Transformation of Amorphous Calcium Phosphate to Hydroxyapatitein Vitro. Calcif. Tissue Res. 1975, 19, 197-210. [CrossRef]

72. Pokhrel, R.; Gerstman, B.S.; Hutcheson, J.D.; Chapagain, P.P. In Silico Investigations of Calcium Phosphate Mineralization in Extracellular Vesicles. J. Phys. Chem. B 2018, 122, 3782-3789. [CrossRef]

73. Brečević, L.; Hlady, V.; Füredi-Milhofer, H. Influence of Gelatin on the Precipitation of Amorphous Calcium Phosphate. Colloids Surf. 1987, 28, 301-313. [CrossRef]

74. Sugiura, Y.; Onuma, K.; Kimura, Y.; Miura, H.; Tsukamoto, K. Morphological Evolution of Precipitates during Transformation of Amorphous Calcium Phosphate into Octacalcium Phosphate in Relation to Role of Intermediate Phase. J. Cryst. Growth 2011, 332, 58-67. [CrossRef]

75. Koutsopoulos, S. Synthesis and Characterization of Hydroxyapatite Crystals: A Review Study on the Analytical Methods. J. Biomed. Mater. Res. 2002, 62, 600-612. [CrossRef]

76. Mochales, C.; Wilson, R.M.; Dowker, S.E.P.; Ginebra, M.-P. Dry Mechanosynthesis of Nanocrystalline Calcium Deficient Hydroxyapatite: Structural Characterisation. J. Alloy. Compd. 2011, 509, 7389-7394. [CrossRef]

77. Dorozhkin, S.V. Amorphous Calcium (Ortho)Phosphates. Acta Biomater. 2010, 6, 4457-4475. [CrossRef]

78. Liou, S.-C.; Chen, S.-Y.; Lee, H.-Y.; Bow, J.-S. Structural Characterization of Nano-Sized Calcium Deficient Apatite Powders. Biomaterials 2004, 25, 189-196. [CrossRef]

79. Merolli, A.; Santin, M. Role of Phosphatidyl-Serine in Bone Repair and Its Technological Exploitation. Molecules 2009, 14, 5367-5381. [CrossRef]

80. Hendrickson, H.S.; Fullington, J.G. Stabilities of Metal Complexes of Phospholipids: Ca(II), Mg(II), and Ni(II) Complexes of Phosphatidylserine and Triphosphoinositide. Biochemistry 1965, 4, 1599-1605. [CrossRef]

81. Andersen, F.A.; Brečević, L.; Beuter, G.; Dell'Amico, D.B.; Calderazzo, F.; Bjerrum, N.J.; Underhill, A.E. Infrared Spectra of Amorphous and Crystalline Calcium Carbonate. Acta Chem. Scand. 1991, 45, 1018-1024. [CrossRef]

82. Andersen, F.A.; Kralj, D. Determination of the Composition of Calcite-Vaterite Mixtures by Infrared Spectrophotometry. Appl. Spectrosc. 1991, 45, 1748-1751. [CrossRef]

83. Larkin, P. Infrared and Raman Spectroscopy: Principles and Spectral Interpretation; Elsevier: Amsterdam, The Netherlands; Boston, MA, USA, 2011; ISBN 978-0-12-386984-5.

84. Grassmann, O.; Müller, G.; Löbmann, P. Organic-Inorganic Hybrid Structure of Calcite Crystalline Assemblies Grown in a Gelatin Hydrogel Matrix: Relevance to Biomineralization. Chem. Mater. 2002, 14, 4530-4535. [CrossRef]

85. Wang, J.; Xu, Y.; Zhao, Y.; Huang, Y.; Wang, D.; Jiang, L.; Wu, J.; Xu, D. Morphology and Crystalline Characterization of Abalone Shell and Mimetic Mineralization. J. Cryst. Growth 2003, 252, 367-371. [CrossRef]

86. Shen, Q.; Chen, Y.; Wei, H.; Zhao, Y.; Wang, D.; Xu, D. Suspension Effect of Poly(Styrene-Ran-Methacrylic Acid) Latex Particles on Crystal Growth of Calcium Carbonate. Cryst. Growth Des. 2005, 5, 1387-1391. [CrossRef]

87. Ihli, J.; Wong, W.C.; Noel, E.H.; Kim, Y.-Y.; Kulak, A.N.; Christenson, H.K.; Duer, M.J.; Meldrum, F.C. Dehydration and Crystallization of Amorphous Calcium Carbonate in Solution and in Air. Nat. Commun. 2014, 5, 3169. [CrossRef]

88. Brečević, L.; Nöthig-Laslo, V.; Kralj, D.; Popović, S. Effect of Divalent Cations on the Formation and Structure of Calcium Carbonate Polymorphs. J. Chem. Soc. Faraday Trans. 1996, 92, 1017-1022. [CrossRef]

89. Picker, A.; Nuss, H.; Guenoun, P.; Chevallard, C. Polymer Vesicles as Microreactors for Bioinspired Calcium Carbonate Precipitation. Langmuir 2011, 27, 3213-3218. [CrossRef]

90. Messersmith, P.B.; Starke, S. Thermally Triggered Calcium Phosphate Formation from Calcium-Loaded Liposomes. Chem. Mater. 1998, 10, 117-124. [CrossRef]

91. Eanes, E.D.; Hailer, A.W. Liposome-Mediated Calcium Phosphate Formation in Metastable Solutions. Calcif. Tissue Int. 1985, 37, 390-394. [CrossRef]

92. Erceg, I.; Selmani, A.; Gajović, A.; Radatović, B.; Šegota, S.; Ćurlin, M.; Strasser, V.; Kontrec, J.; Kralj, D.; Maltar-Strmečki, N.; et al. Precipitation at Room Temperature as a Fast and Versatile Method for Calcium Phosphate/ $\mathrm{TiO}_{2}$ Nanocomposites Synthesis. Nanomaterials 2021, 11, 1523. [CrossRef] 